\title{
Fundamental insights into autosomal dominant polycystic kidney disease from human-based cell models
}

\author{
Caroline Weydert $^{1} \cdot$ Jean-Paul Decuypere ${ }^{1} \cdot$ Humbert De Smedt ${ }^{2} \cdot$ Peter Janssens $^{1,3} \cdot$ Rudi Vennekens $^{4}$. \\ Djalila Mekahli ${ }^{1,5}$
}

Received: 14 February 2018 / Revised: 23 July 2018 / Accepted: 13 August 2018

(C) IPNA 2018

\begin{abstract}
Several animal- and human-derived models are used in autosomal dominant polycystic kidney disease (ADPKD) research to gain insight in the disease mechanism. However, a consistent correlation between animal and human ADPKD models is lacking. Therefore, established human-derived models are relevant to affirm research results and translate findings into a clinical set-up. In this review, we give an extensive overview of the existing human-based cell models. We discuss their source (urine, nephrectomy and stem cell), immortalisation procedures, genetic engineering, kidney segmental origin and characterisation with nephron segment markers. We summarise the most studied pathways and lessons learned from these different ADPKD models. Finally, we issue recommendations for the derivation of human-derived cell lines and for experimental set-ups with these cell lines.
\end{abstract}

Keywords ADPKD $\cdot$ Human cell lines $\cdot$ Calcium $\cdot$ cAMP $\cdot$ mTOR

\section{Introduction}

Autosomal dominant polycystic kidney disease (ADPKD) is the most prevalent monogenetic disease. Estimated to occur in 2.93.3 per 10,000 individuals [1], it leads to end-stage renal disease (ESRD) in half of the cases before the sixth decade of life [2,3]. Cyst formation in all renal segments and increased total kidney volume (TKV) are the hallmarks of ADPKD. Furthermore, ADPKD can be considered as a multi-organ disorder associated

Djalila Mekahli

djalila.mekahli@uzleuven.be

1 PKD Research Group, Laboratory of Pediatrics, Department of Development and Regeneration, GPURE, KU Leuven, Leuven, Belgium

2 Laboratory of Molecular and Cellular Signaling, Department of Cellular and Molecular Medicine, KU Leuven, Leuven, Belgium

3 Department of Nephrology, University Hospitals Brussels, Brussels, Belgium

4 VIB Center for Brain and Disease Research, Laboratory of Ion Channel Research, Department of Cellular and Molecular Medicine, KU Leuven, Leuven, Belgium

5 Department of Pediatric Nephrology, University Hospitals Leuven, Herestraat 49, 3000 Leuven, Belgium with the formation of cysts in other organs (like the liver), hypertension and vascular aneurysms.

ADPKD is caused by mutations in the PKD1 and PKD2 genes, accounting for approximately 78 and $15 \%$ of the affected families [1]. Recently, mutations in other genes (like GANAB) have been identified as a cause of ADPKD. PKD1 and PKD2 encode for polycystin-1 (PC1) and polycystin-2 (PC2) respectively, which are membrane-spanning proteins. Current knowledge indicates that the polycystins form a protein complex in which PC2 functions as a calcium $\left(\mathrm{Ca}^{2+}\right)$-permeable ion channel [4]. The cellular function of $\mathrm{PC} 1$ remains unclear. Dysfunction of these proteins leads to several cellular changes, including alterations in $\mathrm{Ca}^{2+}$ homeostasis, cyclic AMP (cAMP) levels, serine/ threonine-protein kinase mTOR (mTOR) activity and overall metabolism, finally resulting in cyst formation $[5,6]$.

To date, the only available specific treatment for ADPKD patients is tolvaptan, an oral vasopressin receptor-2 (AVPR2) antagonist, which slows down TKV expansion with 50\% and kidney function decline by $38 \%$ after 3 years [7]. However, poor tolerance and rarely severe liver toxicity have been associated with this therapy. Unfortunately, clinical trials with alternatives have so far been disappointing: somatostatin analogues as well as mTOR inhibitors did not result in a sustained, statistically significant reduction of TKV change [8].

Several hurdles hinder ADPKD research. For example, the large size of the $\mathrm{PC} 1$ protein $(\sim 460 \mathrm{kDa})$ complicates 
biochemical research and its function remains largely unknown. In addition, the $P K D 1$ gene is difficult to sequence or manipulate due to duplications of exons 1-33 in the human genome, leading to six $P K D 1$ pseudogenes. Functionally, PC1 and $\mathrm{PC} 2$ regulate not only each other, but apparently a whole set of other proteins involved in a complex network of intracellular pathways [9]. As such, the cellular consequences of a specific mutation remain difficult to predict. This is illustrated by the extensive range of disease-causing mutations and the difference in the observed phenotypes [1]. Finally, it should be noted that there exists a strong research focus on advanced stages of the disease. Studies of early stage disease development might be more useful to understand ADPKD initiation and progression. Indeed, cyst formation and growth already start in utero and a significant increase of TKV is observed in the first decades of life [10].

In this review, we focus on human-derived cell models. We discuss existing cell lines, the results obtained with these cells concerning $\mathrm{PC} 1$ and $\mathrm{PC} 2$ localisation, cilia function, proliferation, $\mathrm{Ca}^{2+}$ signalling, mTOR metabolism and cyst formation. Comparisons with relevant results obtained from animal models are included.

\section{Human PKD cell models: an overview}

Since the first ADPKD patient-derived cell-based research in 1986 [11], a plethora of human-derived cell systems have been used in ADPKD research (Tables 1 and 2). These systems differ by means of cell origin, genetic modification, level of validation and PKD mutations (Tables 1 and 2). Most primary cells are not included in these tables, as they are not immortalised and therefore unique. However, valuable results have been obtained from primary cell preparations and are discussed below.

\section{Patient-derived and genetically engineered human cell lines}

Cells and cell lines used in ADPKD research are derived from cysts (mainly obtained after nephrectomy) [16, 19, 21, 27-34], from cells shed in urine [22] and from inducible pluripotent (kidney) stem cells (Table 1) [35, 36]. Most cystderived cell lines originated from nephrectomised, end-stage kidneys. As such, they represent an advanced disease stage and are probably not suitable to identify initiators of cyst progression. Furthermore, cystic material from patients with $P K D 2$ mutations is underrepresented in these studies, as in these patients ESRD and nephrectomy are relatively rare. Yet, a significant party of the fundamental ADPKD research field focuses on the loss of $P K D 2$. Taken together, only a handful of $P K D 1$ and $P K D 2$ mutations have been explored (Table 1). Clearly, results can be influenced by the genetic donor background and the epithelial origin of control and ADPKD cell lines (see section below).

An alternative source of patient-derived cells is urine. Humans shed epithelial cells via their urine, which can be selectively cultured and characterised [22], even in the case of PKD2-based ADPKD. Despite these advantages, it is not clear to what extent these cells represent cyst-forming cells. Therefore, further validation of this model is necessary.

Human pluripotent stem cells are another interesting source for ADPKD research [25, 35-37]: both embryonic stem cell lines (hESCs) and induced pluripotent stem cell lines (iPSCs) with patient-specific mutations or artificially edited genes can be of value (see below and Tables 1 and 2). An interesting feature of hPSC-derived kidney cell lines (hPSC-KC, which originate from hPSCs and express kidney markers) is their capability to form epiblast spheroids and subsequently tubular organoids [36]. Whether these cells exhibit all features of mature epithelial cells is a matter of debate.

Finally, genetically engineered knockdown (KD) and knockout (KO) cell lines are useful cell models in ADPKD research. Although they do not necessarily represent $P K D 1$ mutations found in ADPKD patients, they allow investigation of the primary functions of the polycystins and the fundamental pathways involved in ADPKD. For example, PKD1 and $P K D 2 \mathrm{KD}$ mimic the changes in mTOR activity and proliferation observed in animal models and patient cell lines $[22,38]$. This phenotype is in agreement with the observation that $P K D 1 \mathrm{KD}$ is sufficient to induce cystogenesis in animal models and animal-derived cell lines [39-41]. Recently, the first biallelic $P K D 1$ and $P K D 2$ frameshift mutations have been engineered with CRISPR-Cas9 in cell lines derived from hPSC-KCs, showing more cyst formation compared to hPSC-KC controls (Table 2) [36].

\section{Genetic modification for immortalisation and stem cell reprogramming purposes}

Patient-derived primary cells are obviously the model of choice, but limitations exist concerning their accessibility, life span and origin. Until now, primary cells used in ADPKD research were derived from patients with advanced stages of disease. This might make it difficult to derive cyst-initiating factors from this source. On the other hand, it is worth realising that a subtle ADPKD cellular phenotype might be overwhelmed or altered because of the immortalisation procedure to create a cell line. A brief comparison between primary cells and cell lines is made in Table 3.

To derive stable cell lines, several immortalisation protocols have been used, of which the effect of both the oncogene and the used (viral) carrier have to be considered (Table 1). Often (retroviral or adenoviral assisted) genomic insertion of SV40 large T antigen (SV40 LT) and SV40 LT antigen mutants is used $[12,16]$. This dominant oncogene originating 


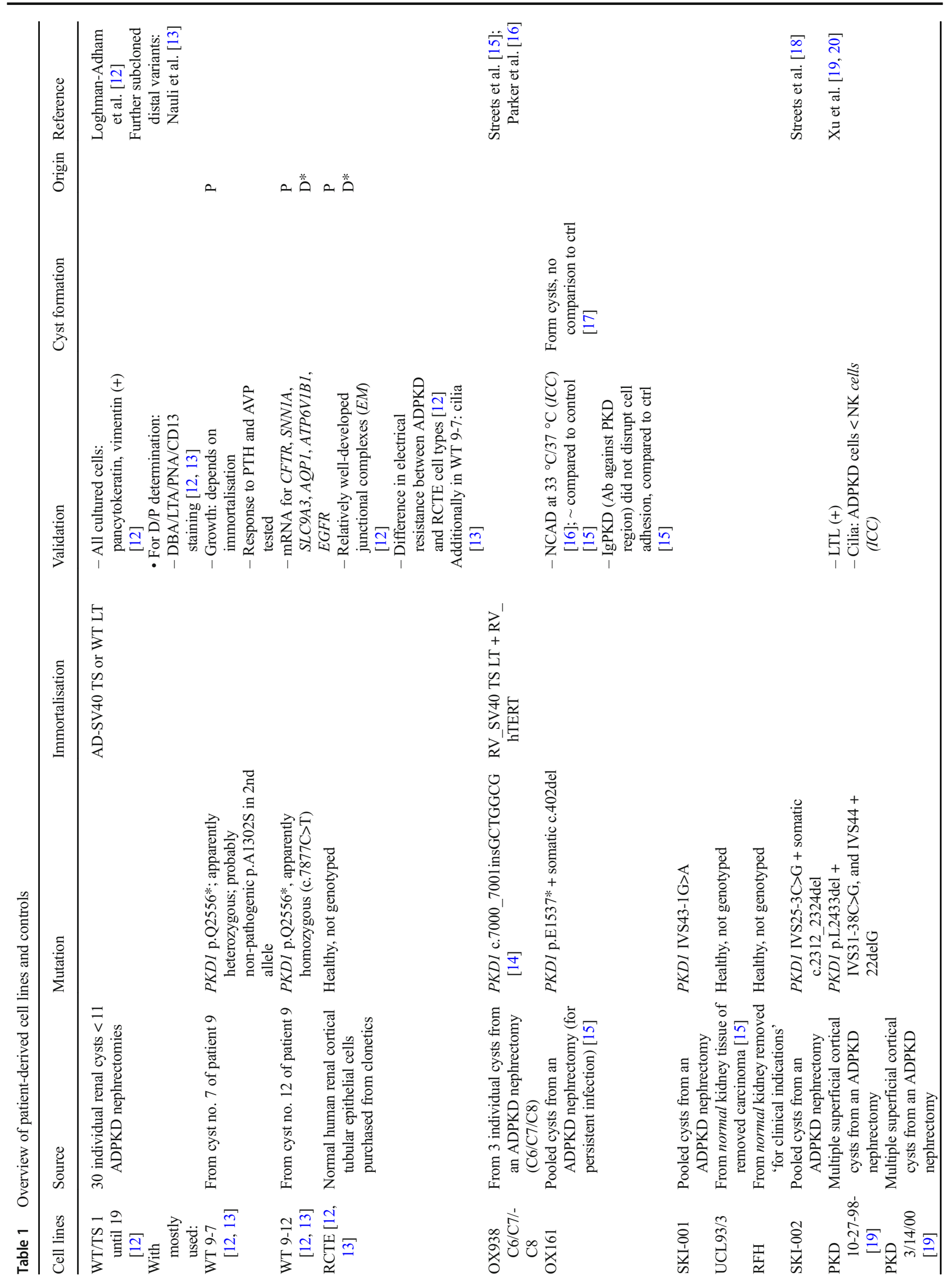




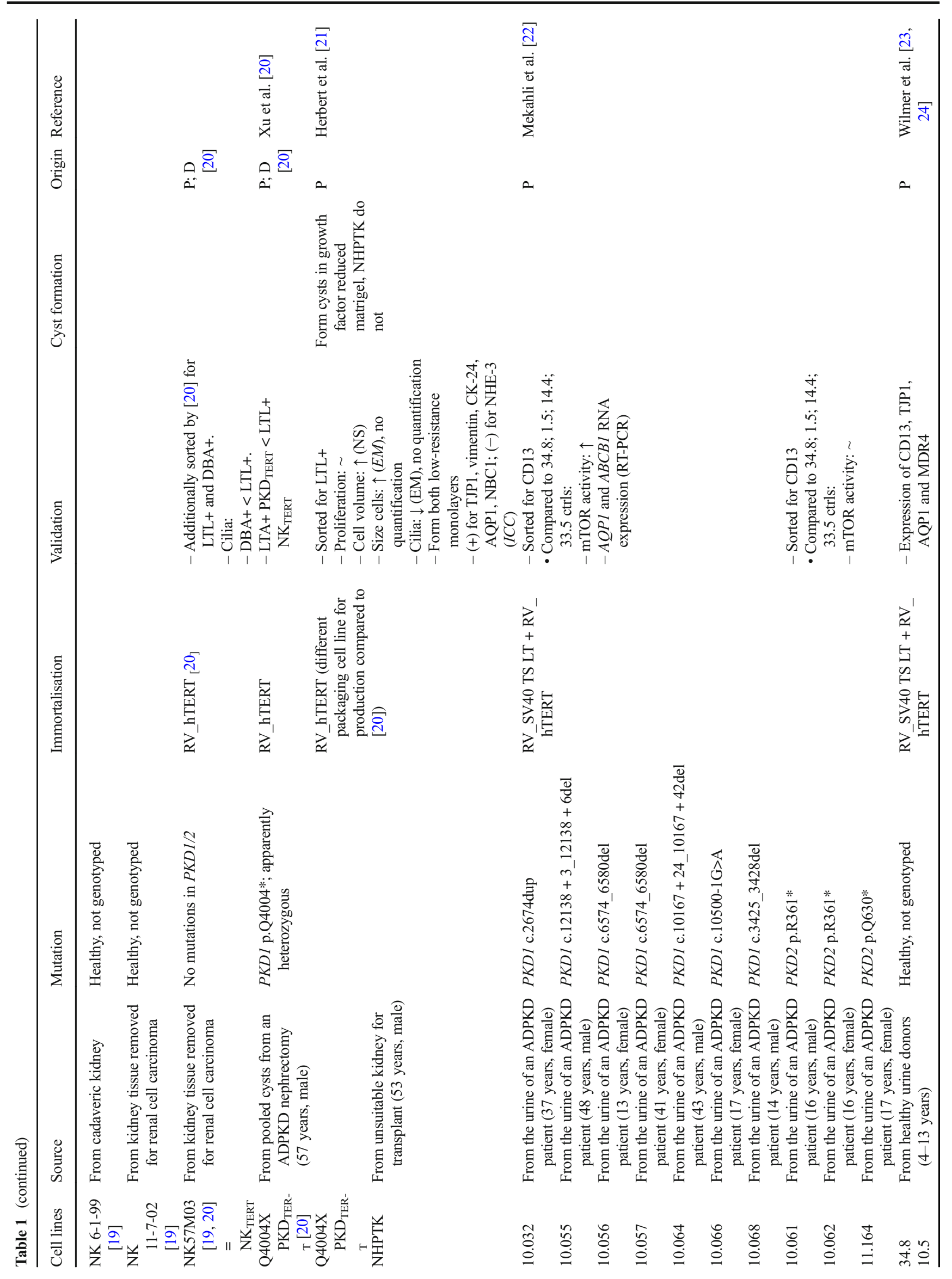




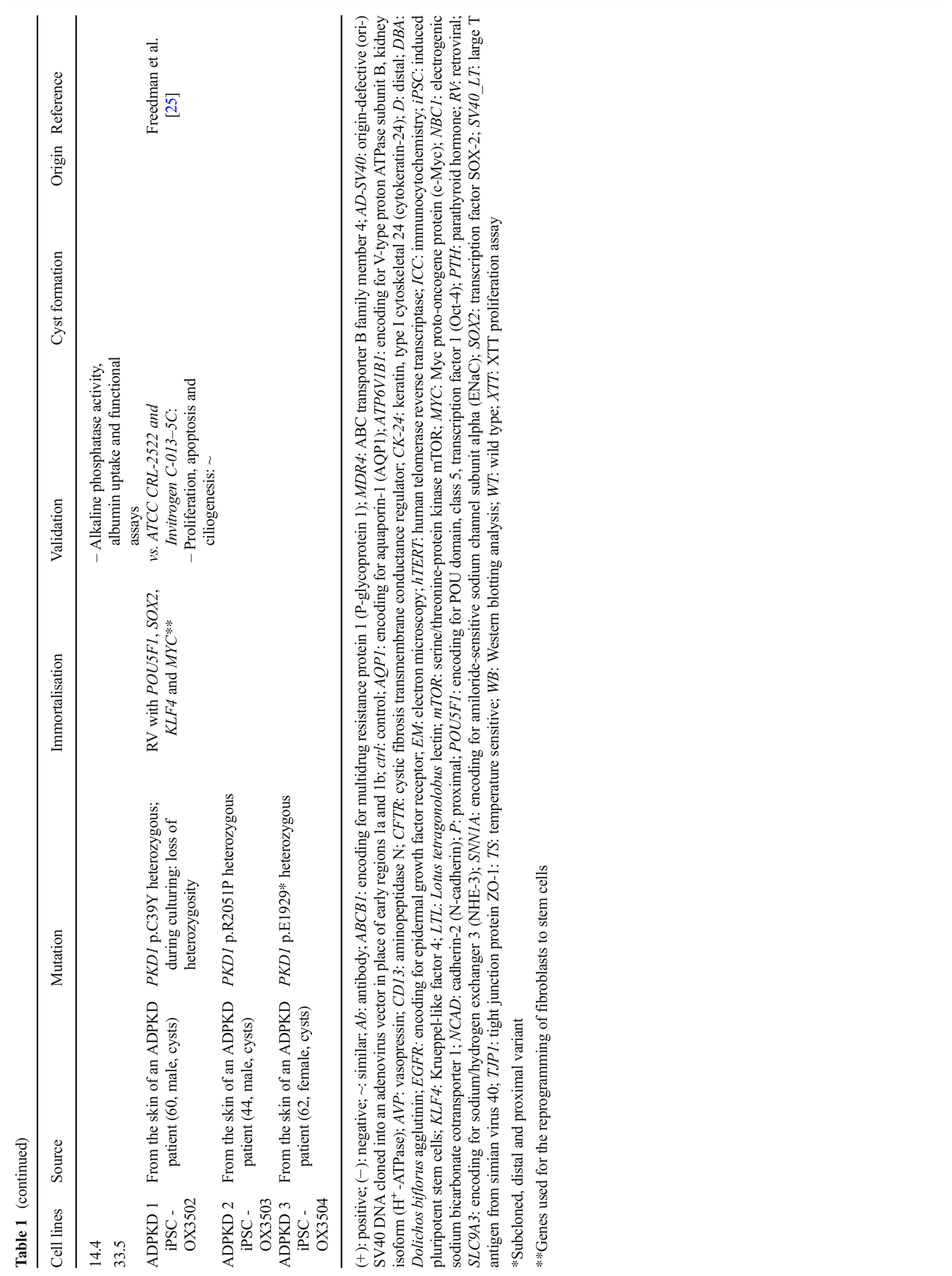




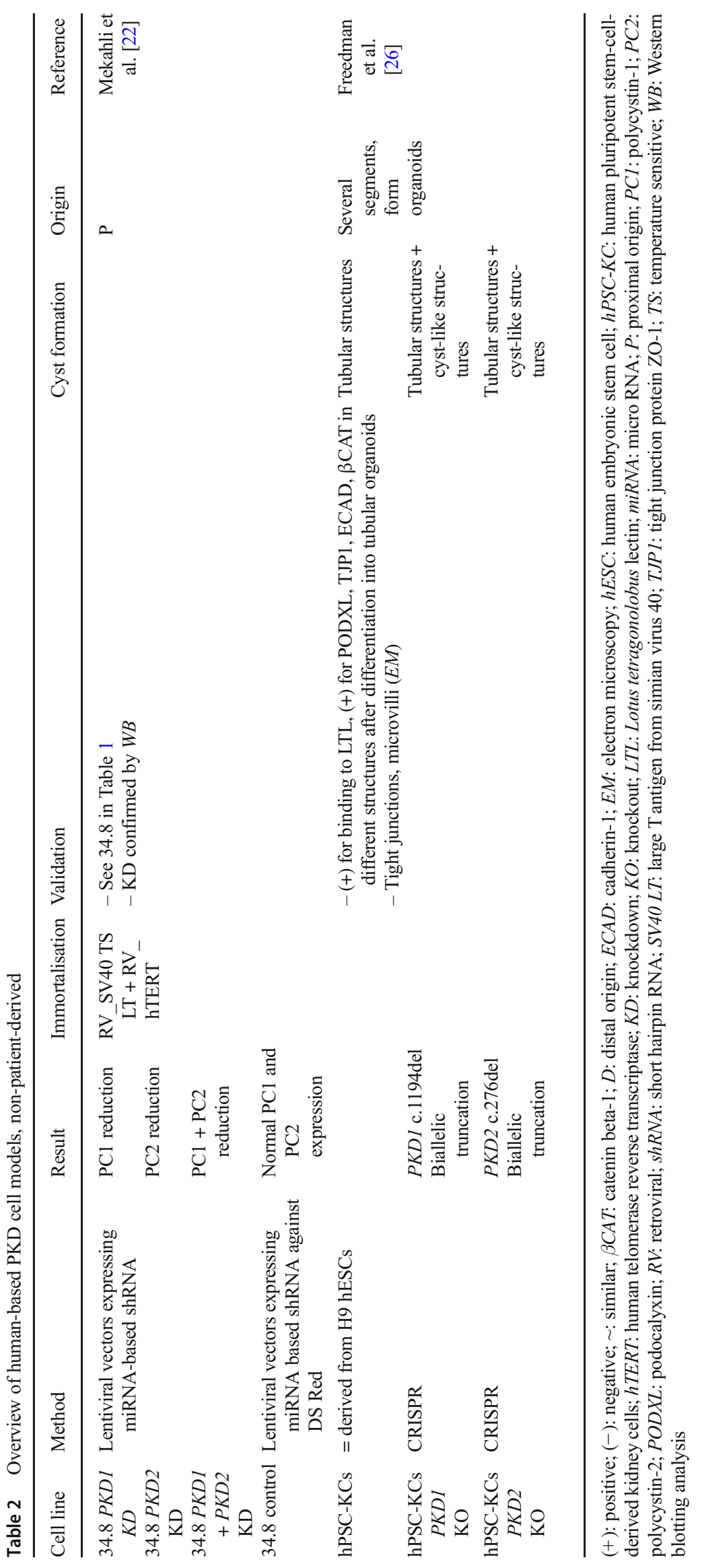


Table 3 Brief comparison of primary cells and cell line characteristics

\begin{tabular}{|c|c|c|}
\hline & Primary cells & Cell lines, stem cells* \\
\hline $\begin{array}{l}\text { Isolation } \\
\text { from }\end{array}$ & $\begin{array}{l}\text { Nephrectomy (cysts) } \\
\quad(\text { e.g., }[27,29,42-44])\end{array}$ & $\begin{array}{l}\text { Nephrectomy (cysts), urine } \\
{[22],} \\
\text { skin*/blood*/embryonic* } \\
{[25,35,36]}\end{array}$ \\
\hline Accessibility & Limited & Unlimited \\
\hline Life span & Short (4-6 passages) [27] & $\begin{array}{l}\text { Longer, but should } \\
\text { preferentially be used } \\
\text { between a defined passage } \\
\text { window }\end{array}$ \\
\hline Alterations & $\begin{array}{l}\text { Due to culturing } \\
\text { conditions }\end{array}$ & $\begin{array}{l}\text { Due to culturing conditions } \\
\text { Due to immortalisation [ } 45 \text {, } \\
\quad 46]\end{array}$ \\
\hline $\begin{array}{c}\text { Nephron } \\
\text { origin }\end{array}$ & $\begin{array}{l}\text { Often unknown or } \\
\text { minimally validated } \\
(\text { e.g., }[27,29,42-44]) \\
\text { Typically mixed } \\
\text { population }\end{array}$ & $\begin{array}{l}\text { Validation can be performed } \\
\text { more in depth (see Table 1) } \\
\text { Can be subcloned (see Table 1) }\end{array}$ \\
\hline $\begin{array}{r}\text { Disease } \\
\text { stage }\end{array}$ & $\begin{array}{l}\text { Mostly end-stage (e.g., } \\
[27,29,42-44])\end{array}$ & $\begin{array}{l}\text { Both early and end-stage } \\
\text { possible, according to the } \\
\text { cell type }\end{array}$ \\
\hline $\begin{array}{l}\text { Germline } \\
\text { mutation }\end{array}$ & $\begin{array}{l}\text { Often not determined, but } \\
\text { possible [19] }\end{array}$ & Mostly determined (see Table 1) \\
\hline
\end{tabular}

*For the specific case of hPSCs/iPSCs

from simian virus, its interference with the $\mathrm{p} 53$ and $\mathrm{Rb}$-family of tumour suppressors is well established [45]. Hence, SV40 LT itself might be cystogenic [47]. This can be avoided by immortalising with the temperature-sensitive SV40 tsA58 (U19) or SV40 tsA209 (SV40 TS) mutants [23, 48, 49]. These cells do not express the large $\mathrm{T}$ antigen at non-permissive temperatures $\left(37-39^{\circ} \mathrm{C}\right)$ enabling differentiation. A drawback is that cultivation occurs at $33^{\circ} \mathrm{C}$ in order to retain large $\mathrm{T}$ antigen expression, which slows down metabolic processes and cell growth. Another disadvantage is the influence of SV40 LT on cell growth: growth of PKD-cell lines was mainly dependent upon the applied immortalisation process and not upon their origin [12]. In each of these approaches, senescence can occur, which has been circumvented by the additional presence of a retroviral vector that expresses the catalytic subunit of the human telomerase reverse transcriptase (hTERT) (Table 1) [16, 22]. Some groups also managed to immortalise cells using solely a retroviral construct expressing hTERT [20,21]. hTERT is believed to interfere to a lesser extent with cellular processes compared to SV40 LT, in particular considering JAK/STAT, Myc and Src pathways [19, 21, 31]. Nonetheless, hTERT-mediated immortalisation will also affect proliferation, for example through the Wnt and NF- $\mathrm{KB}$ pathways [46]. Not only is the particular oncogene of importance, but also the vector backbone and titers: for example, MLV-based $\gamma$-retroviral vectors can already have oncogenic effects by integrating nearby promotor and transcription start sites [50]. Furthermore, it has been shown that by reprogramming cells using retroviral vectors (illustrated by the iPCs in Table 1), additional mutations occur that influence cellular features [25]. Thus, when comparing cell lines, the immortalisation process is an important feature to consider.

\section{The necessity of a meticulous characterisation}

The detection of several markers indicates the origin from a specific nephron segment. Despite their frequent use in nephrology research, the specificity of these markers is rarely absolute and ADPKD cyst-derived cells seem to show signs of dedifferentiation, including downregulation of several nephron segment markers [9]. Furthermore, dedifferentiation also occurs through immortalisation and cell culturing. For example, both control NHPTK and ADPKD Q4004X lines (Table 1) express vimentin, a marker for mesenchymal and progenitor cells, which is upregulated by hTERT $[21,51]$.

Detection of cytokeratin and cell-adhesion molecules is often used to confirm epithelial origin of cell lines. However, not every epithelial marker is expressed abundantly in every kidney segment. E-cadherin for example, which is used to follow epithelial mesenchymal transition (EMT), is not (or only weakly) detected in proximal tubules [52].

Several markers have been used to define proximal tubular origin of cells (Fig. 1). However, it should be considered that some of these markers are not exclusively expressed in this segment. Aquaporin-1 (AQP1) and sodium-hydrogen exchanger 3 (NHE3) are also highly expressed in the descending limb of the loop of Henle $[53,59]$. Also, multidrug resistance protein 1 (MDR1, P-glycoprotein 1 or CD243, encoded by $A B C B 1$ ) and multidrug resistance-associated protein 4 (MRP4, encoded by ABCC4) are (weakly) detected in other nephron segments [60-62].

Binding to Lotus tetragonolobus lectin (LTL) and detection of membrane alanyl aminopeptidase (CD13, encoded by $A N P E P)$ and Neprilysin (CD10, encoded by $M M E$ ) are often exploited for sorting and detection of proximal tubule cells [22, 23, 63] (Fig. 1). Nevertheless, LTL also binds to cells of the descending loop of Henle and moderately to the collecting duct [64]. Furthermore, cell lines tend to lose expression of CD13 over time and both CD13 and CD10 are used as fibroblast and vascular endothelial cell markers [65-67].

As cyst formation is argued to start in the collecting ducts [68], obtaining these cells is of large interest for ADPKD research. To this end, cells positive for binding to the lectin dolichos bifloris agglutinin (DBA) or peanut agglutinin (PNA) are collected (Table 1). Yet, cells originating from the loop of Henle and distal convoluted tubules can also bind to these lectins [69]. Discrimination can be made by staining for the solute carrier family 12 member 1 (the kidney specific NaK-Cl-symporter, NKCC2, encoded by SLC12A1) and solute carrier family 12 member 3 (the $\mathrm{Na}-\mathrm{Cl}$ cotransporter, $\mathrm{NCC}$, encoded by $S L C 12 A 3$ ), which are markers for the loop of 


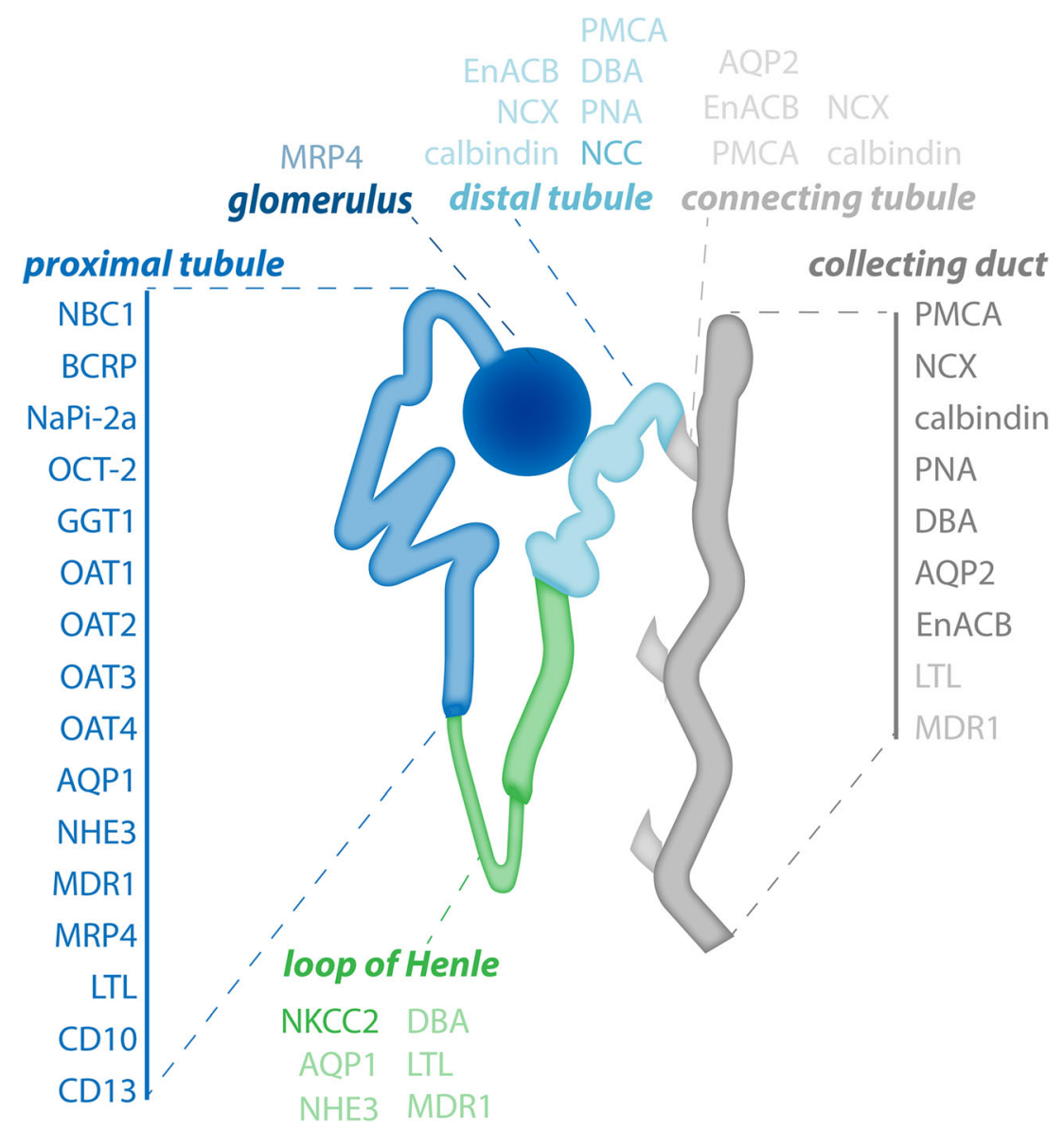

Fig. 1 Markers for nephron segments. Depicted are commonly used markers for epithelial cells originating from the proximal tubule (dark blue), collecting ducts (dark grey), loop of Henle (green) and distal tubule (light blue). Markers also (weakly) staining other segments are depicted at the respective segment in a lighter colour. AQP1: aquaporin-1; NHE3: the sodium-hydrogen antiporter 3 (encoded SLC9A3); NBC1: electrogenic sodium bicarbonate cotransporter 1 (encoded by $S L C 4 A 4$ ); NaPi-2a: sodium-dependent phosphate transport protein 2A (encoded by SLC34A1) [53-55]; OCT-2: solute carrier family 22 member 2 (also known as Organic cation transporter 2, encoded by SLC22A2); OAT1: solute carrier family 22 member 6 (encoded by

Henle and distal convoluted tubules [70]. Several other commonly used markers also stain multiple segments (Fig. 1).

In conclusion, it is advised to use an extensive panel of (positive and negative) markers in order to determine the origin of a cell line. Considering the putative dedifferentiation of ADPKD cystic cell lines, this approach clearly has limitations considering the determination of the segmental origin of cystic cells.

\section{Lessons learned}

A plethora of pathways is altered in the described ADPKD cell models [71]. Furthermore, recent papers have investigated the transcriptome in human ADPKD cyst-derived cell lines,
SLC22A6); OAT3: solute carrier family 22 member 8 (encoded by SLC22A8); OAT4: solute carrier family 22 member 11 [56, 57]; GGT1: glutathione hydrolase 1 proenzyme (CD224) [58]; BRCP: ATP-binding cassette sub-family G member 2; LTL: Lotus tetragonolobus Lectin; CD13: membrane alanyl aminopeptidase; CD10: Neprilysin; NKCC2: solute carrier family 12 member 1 (or kidney-specific Na-K-Clsymporter, encoded by SLC12A1); NCC: solute carrier family 12 member 3 (or Na-Cl cotransporter, encoded by SLC12A3); PMCA: plasma membrane calcium-transporting ATPase; NCX: sodium/calcium exchanger; EnACB: amiloride-sensitive sodium channel subunit beta; AQP2: aquaporin-2

producing a set of data for further research [31]. In this review, we will focus on the influence of ADPKD on cilia function, proliferation, $\mathrm{Ca}^{2+}$ signalling, cAMP and mTOR metabolism, as studied in human-based cell models.

\section{PC1 and PC2 localisation and expression}

Most cystic- and urine-derived ADPKD cell lines show absent or decreased levels of full-length PC1 compared to controls (Table 4), while a few ADPKD-derived cell lines show similar global $\mathrm{PC} 1$ expression levels as healthy controls $[12,16,19-22,25]$. On the other hand, all tested human-derived $P K D 1$ cell lines seem to have little or no $\mathrm{PC} 1$ in primary cilia (see section "Cilia function and ADPKD") and at the plasma membrane [12, 21]. In the majority of $P K D 1$-mutated cell lines, a ciliary $\mathrm{PC} 2$ reduction 
Table $4 \quad$ PC1 and PC2 expression and localisation

\begin{tabular}{|c|c|c|c|c|c|c|c|c|c|}
\hline Cell lines & Mutation & $\begin{array}{l}\text { PC1 total }(W B / \\
R T-P C R / I C C)\end{array}$ & $\begin{array}{l}\mathrm{PC} 1 \\
\mathrm{PM} / \mathrm{ER} \\
(I C C)\end{array}$ & $\begin{array}{l}\mathrm{PC} 1 \\
\text { Cilia } \\
(I C C)\end{array}$ & $\begin{array}{l}\text { PC2 total } \\
(W B / R T- \\
P C R / I C C)\end{array}$ & $\begin{array}{l}\mathrm{PC} 2 \\
\mathrm{PM} / \mathrm{ER} \\
(I C C)\end{array}$ & $\begin{array}{l}\text { PC1 Cilia } \\
(I C C)\end{array}$ & Compared to & Reference \\
\hline $\begin{array}{l}\text { WT/TS } \\
1-19[12]\end{array}$ & & $\begin{array}{l}(+)(R T-P C R / \\
I C C)\end{array}$ & & & & & & & $\begin{array}{l}\text { Loghman-Adham } \\
\text { et al. [12] }\end{array}$ \\
\hline $\begin{array}{l}\text { With } \\
\text { mostly } \\
\text { used: }\end{array}$ & & & & & & & & & $\begin{array}{l}\text { Further subcloned } \\
\text { distal variants: } \\
\text { Nauli et al. [13] }\end{array}$ \\
\hline $\begin{array}{l}\text { WT 9-7 } \\
\quad[12,13]\end{array}$ & $\begin{array}{l}P K D 1 \text { p.Q2556*; } \\
\text { apparently } \\
\text { heterozygous }\end{array}$ & $\downarrow$ (WB) [13] & & & & & & RCTE & \\
\hline $\begin{array}{l}\text { WT 9-12 } \\
\qquad[12,13]\end{array}$ & $\begin{array}{l}\text { PKD1 p.Q2556*, } \\
\text { apparently } \\
\text { homozygous }\end{array}$ & $\begin{array}{l}\text { FL: }(-)(W B) \\
\quad[13]\end{array}$ & & ${ }_{[13]}^{(-)}$ & $\sim(W B)[13]$ & & $\downarrow[13]$ & & \\
\hline $\begin{array}{l}\text { OX938 C6/ } \\
\text { C } 7 / \mathrm{C} 8\end{array}$ & $\begin{array}{l}\text { PKD1 c.7000_ } \\
\quad 7001 \text { insGCTGGCG } \\
\quad[14]\end{array}$ & $(-)(W B)$ & & & $\sim(W B)$ & & & UCL93/3 & $\begin{array}{l}\text { Streets et al. [15]; } \\
\quad \text { Parker et al. [16] }\end{array}$ \\
\hline OX161 & $\begin{array}{l}\text { PKD1 p.E1537* + } \\
\text { somatic c. } 402 \mathrm{delG}\end{array}$ & $\downarrow(W B)[15,16]$ & & & $\begin{array}{l}\sim(W B)[15, \\
\quad 16]\end{array}$ & & & & \\
\hline SKI-001 & $P K D 1$ IVS43-1G $>\mathrm{A}$ & $\downarrow(W B)$ & & & $\sim(W B)$ & & & & \\
\hline $\begin{array}{l}\text { PKD } \\
\qquad \begin{array}{l}10-27-98 \\
{[19]}\end{array}\end{array}$ & $\begin{array}{l}P K D 1 \text { p.L2433del + } \\
\text { IVS31-38C }>\mathrm{G} \text { and } \\
\text { IVS44 + 22delG }\end{array}$ & $\sim(\mathrm{WB}) ; \mathrm{FL} \downarrow$ & & $(-)$ & $\sim(\mathrm{WB})$ & & In $30 \%$ & NK & $\mathrm{Xu}$ et al. $[19,20]$ \\
\hline $\begin{array}{l}\text { PKD } \\
\quad 3 / 14 / 00 \\
{[19]}\end{array}$ & & & & & & & & & \\
\hline $\begin{array}{l}\text { Q4004X } \\
\text { PKD } \\
\text { TERT [20] }\end{array}$ & $\begin{array}{c}P K D 1 \text { p.Q4004* } \\
\text { heterozygous }\end{array}$ & $\begin{aligned} \sim & (W B) \neq \\
& \text { fragments in } \\
& \text { exosomes } \\
& {[21] }\end{aligned}$ & $\begin{array}{c}\downarrow \text { @ PM } \\
{[21]}\end{array}$ & $(-)[19]$ & $\begin{array}{c}\uparrow(W B) ; \neq \\
\text { splice } \\
\text { variants } \\
{[21]}\end{array}$ & & $\begin{array}{c}\text { Almost }(-) \\
{[20]}\end{array}$ & $\begin{array}{l}\text { NK57M03 [20] } \\
\text { NHPTK [21] }\end{array}$ & $\begin{array}{l}\text { Xu et al. [20] } \\
\text { Herbert et al. [21] }\end{array}$ \\
\hline 10.032 & $P K D 1$ c.2674dup & $\downarrow(W B)$ & & & $\sim(W B)$ & & & 34.8 & Mekahli et al. [22] \\
\hline 10.055 & $\begin{array}{c}P K D 1 \text { c. } 12138+3- \\
12138+6 \mathrm{del}\end{array}$ & & & & & & & $\begin{array}{l}10.5 \\
14.4\end{array}$ & \\
\hline 10.056 & PKDI c.6574_6580del & & & & & & & 33.5 & \\
\hline 10.057 & PKD1 c.6574_6580del & & & & & & & & \\
\hline 10.064 & $\begin{array}{c}P K D 1 \text { c. } 10167+24 \\
10167+42 \mathrm{del}\end{array}$ & & & & & & & & \\
\hline 10.066 & $P K D 1$ c. $10500-1 \mathrm{G}>\mathrm{A}$ & & & & & & & & \\
\hline 10.068 & PKD1 c.3425_3428del & & & & & & & & \\
\hline 10.061 & $P K D 2$ p.R361* & & & & $\downarrow(W B)$ & & & & \\
\hline 10.062 & $P K D 2$ p.R361* & & & & & & & & \\
\hline 11.164 & $P K D 2$ p.Q630* & & & & & & & & \\
\hline $\begin{array}{l}\text { ADPKD } 1 \\
\text { iPSC - } \\
\text { OX3502 }\end{array}$ & $\begin{array}{l}\text { PKD1 p.C39Y - loss of } \\
\text { heterozygosity }\end{array}$ & $\sim(W B)$ & $\begin{array}{l}\text { Antibody to } \\
\text { aspecific }\end{array}$ & & $\sim(W B)$ & $\sim$ & $\begin{array}{l}\downarrow \text {; rescue by } \\
\quad \text { functional } \\
\quad \mathrm{PC} 1 \uparrow\end{array}$ & $\begin{array}{l}\text { ATCC CRL-2522 } \\
\text { and Invitrogen } \\
\text { C-013-5C: }\end{array}$ & Freedman et al. [25] \\
\hline $\begin{array}{l}\text { ADPKD } 2 \\
\text { iPSC - } \\
\text { OX3503 }\end{array}$ & $\begin{array}{c}P K D 1 \text { p.R2051P } \\
\text { heterozygous }\end{array}$ & & & & & & & & \\
\hline $\begin{array}{l}\text { ADPKD } 3 \\
\text { iPSC - } \\
\text { OX3504 }\end{array}$ & $\begin{array}{c}P K D 1 \text { p. E1929* } \\
\text { heterozygous }\end{array}$ & $\begin{array}{l}\downarrow \text {, additional } \\
\quad \text { band at } \\
250 \mathrm{kDA} \\
(W B)\end{array}$ & $\begin{array}{r}\text { Antibody to } \\
\text { aspecific }\end{array}$ & & $\sim(W B)$ & & & & \\
\hline $\begin{array}{c}34.8 P K D 1 \\
K D\end{array}$ & $\begin{array}{l}\text { Lentiviral vectors } \\
\text { expressing }\end{array}$ & $\begin{array}{l}\downarrow \text { (almost }(-), \\
W B)\end{array}$ & & & $\sim(W B)$ & & & 34.8 control & Mekahli et al. $[22,38]$ \\
\hline $\begin{array}{l}34.8 \text { PKD2 } \\
\mathrm{KD}\end{array}$ & miRNA-based shRNA & $(+)(W B)$ & & & $(-)(W B)$ & & & & \\
\hline $\begin{array}{l}34.8 \text { PKD1 } \\
\quad+P K D 2 \\
\quad \mathrm{KD}\end{array}$ & & $(-)(W B)$ & & & $(-)(W B)$ & & & & \\
\hline
\end{tabular}


Table 4 (continued)

\begin{tabular}{|c|c|c|c|c|c|c|c|c|c|}
\hline Cell lines & Mutation & $\begin{array}{l}\text { PC1 total }(W B / \\
R T-P C R / I C C)\end{array}$ & $\begin{array}{l}\mathrm{PC} 1 \\
\mathrm{PM} / \mathrm{ER} \\
(I C C)\end{array}$ & $\begin{array}{l}\text { PC1 } \\
\text { Cilia } \\
(I C C)\end{array}$ & $\begin{array}{l}\mathrm{PC} 2 \text { total } \\
(W B / R T- \\
P C R / I C C)\end{array}$ & $\begin{array}{l}\mathrm{PC} 2 \\
\mathrm{PM} / \mathrm{ER} \\
(I C C)\end{array}$ & $\begin{array}{l}\text { PC1 Cilia } \\
(I C C)\end{array}$ & Compared to & Reference \\
\hline $\begin{array}{c}\text { hPSC-KCs } \\
\text { PKD1 } \\
\text { KO }\end{array}$ & $\begin{array}{l}\text { PKDI c.1194del CRISPR } \\
\text { Biallelic truncation }\end{array}$ & $\mathrm{PC}_{\mathrm{FL}}:(-)(W B)$ & & & & & & hPSC-KCs & Freedman et al. [26] \\
\hline $\begin{array}{c}\text { hPSC-KCs } \\
\text { PKD2 } \\
\text { KO }\end{array}$ & $\begin{array}{l}\text { PKD2 c.276del CRISPR } \\
\text { Biallelic truncation }\end{array}$ & & & & & $(-)(W B)$ & & & \\
\hline
\end{tabular}

$(+)$ : positive; $(-)$ : negative; $\sim$ : similar; $\downarrow$ : decrease; $\uparrow:$ increase; $\neq$ : distinct; $D$ : distal origin; $E M$ : electron microscopy; $E R$ : endoplasmic reticulum; $F L$ : full length; $h E S C$ : human embryonic stem cell; $h P S C-K C$ : human pluripotent stem-cell-derived kidney cells; KD: knockdown; KO: knockout; miRNA: micro RNA; $P$ : proximal origin; $P C 1$ : polycystin-1; $P C 2$ : polycystin-2; $P M$ : plasma membrane; shRNA: short hairpin RNA; WB: Western blotting analysis

was observed, despite no differences in global PC2 expression (see section "Cilia function and ADPKD") [12, 19, 25].

\section{Cilia function and ADPKD}

The primary cilium, an organelle involved in mechano- and chemosensing, harbours several proteins encoded by genes commonly mutated in renal disease [72]. ADPKD is considered a 'ciliopathy' as PC1 and PC2 are at least partially located in the primary cilium [73]. Several observations in animal models and human-derived cell lines point towards a contribution of an altered ciliary response in ADPKD progression [30, 72, 74, 75]: (1) an altered position of the basal body, required for signalling in $P k d l \mathrm{KO}$ mice; (2) reduced cyst formation in ADPKD mice models lacking cilia; and (3) reduced $\mathrm{Ca}^{2+}$-response upon fluid-shear stress in human- and mice-derived ADPKD models [13].

As mentioned above, ADPKD is associated with lower ciliary PC1 and PC2 expression: in several cell lines (WT 9-12, WT 9-7,

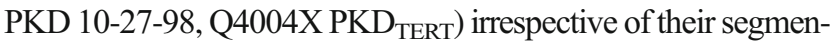
tal origin, mutation, zygosity and global PC1 expression, no PC1 could be detected in cilia [12, 19-21]. PC2 expression in cilia was reduced in all reported human ADPKD-derived cell lines: from undetectable in cilia to a $70 \%$ reduction in cells with detectable PC2 [12, 19-21, 25]. Ciliary PC2 levels were restored after backcomplementation with a functional $P K D 1$ construct in hepatoblasts derived from ADPKD iPSC [25]. These findings were confirmed in several mammalian cell lines, where overexpression of $\mathrm{PC} 1$ influenced $\mathrm{PC} 2$ localisation in primary cilia [4, $25,76]$. In contrast, in a homozygous $P k d 1 \mathrm{KO}$ model, $\mathrm{PC} 2$ was still detectable in the primary cilium [77]. In conclusion, $P K D 1$ mutations seem to affect $\mathrm{PC} 1$ and $\mathrm{PC} 2$ localisation in the cilium, irrespective of immortalisation, origin, mutation and zygosity of cultured human ADPKD-derived cell lines. Finally, the cell line harbouring the truncating p.Q4004* mutation, as well as cells with p.L2433del (Table 1), had shorter cilia compared to the respective controls $[19,21]$. This is in contrast to $P k d I^{\mathrm{del} 34 / \mathrm{del} 34}$ mice harbouring normal ciliary length [30].
These findings correlate with a distinct shear stress response observed in several human-derived ADPKD cystic cell lines. WT 9-7 and 9-12 cells (p.Q2556*, Table 1) show no cytosolic $\mathrm{Ca}^{2+}$-response upon fluid-shear stress, unlike control renal cortical tubular epithelial cells (RCTE) cells $[13,30]$. Similar observations were made in primary PKD cells and a retroviral hTERT-immortalised PKD cell line (p.L2433del, Table 1) $[13,19,20]$.

\section{Proliferation in ADPKD}

Although it is generally accepted that cystogenic cells lacking functional polycystins in/ex vivo exhibit uncontrolled proliferation, results are less clear in vitro. Overexpression of heterologous genes, dominant negative constructs and observations in cells derived from $\mathrm{KO}$ mice hint to an inverse relationship between functional $\mathrm{PC} 1$ dosage and proliferation. For instance, Mekahli et al. observed that PKD1 KD cell lines grow faster compared to control cell lines [22]. In contrast, most tested primary cells derived from ADPKD cysts showed no difference in serum-induced proliferation compared to cells derived from kidneys unsuited for transplantation [21, 27]. It has to be pointed out that the segmental origin of these cells and their genotype are not clearly defined. Furthermore, animal studies indicate that hyperproliferation mainly occurs in early stages of disease, and less in large cysts of the failing kidney [78]. Additionally, ADPKD-derived iPSCs and the $\mathrm{Q}_{4004 \mathrm{X}_{\mathrm{TERT}}}$ cell line showed no difference in (seruminduced) proliferation rate, compared to appropriate control cell lines [21, 25]. ADPKD WT 9-12 cells also showed no (serum-induced) increased proliferation compared to normal kidney HK-2 cells [79]. However, the latter cells were differently immortalised, which could have influenced these results. Indeed, Loghman-Adham et al. demonstrate that the growth rate of patient-derived cell lines seems mainly dependent on the type of immortalisation: WT 9-12 cell lines immortalised with Adv-SV40 LT grow almost twice as fast as TS 9-12 cell lines immortalised with the temperature-sensitive variant [12]. 
Nonetheless, differences in proliferation rates were observed in response to several stimuli: the cyst-derived OX161, OX938 C8 and SKI-001 ADPKD cell lines (Table 1) grew faster compared to UCL93, RFH and CL-11 control cell lines (Table 1) when stimulated with insulin-like growth factor-1 (IGF-1), dbcAMP or cAMP agonists like forskolin and 3-isobutyl-1-methylxanthine (IBMX) (see section below) [16]. Primary ADPKD-derived cells showed increased proliferation (and apoptosis) under stimulation with membrane-permeable cAMP analogues, cAMP agonists, ouabain, vasopressin $(\mathrm{AVP})$ and various other growth-stimulating compounds [43, 80, 81].

\section{Aberrant $\mathrm{Ca}^{2+}$ signalling in ADPKD}

From different ADPKD models, it is clear that cellular $\mathrm{Ca}^{2+}$ signalling is altered. Indeed, $\mathrm{PC} 2$ is a non-selective $\mathrm{Ca}^{2+}$-permeable channel [82] and $\mathrm{PC} 1$ might regulate several $\mathrm{Ca}^{2+}$ permeable ion channels (see below and [83]), including PC2 [4]. Mutations in $\mathrm{PC} 1$ and $\mathrm{PC} 2$ or lack of the respective proteins can therefore result in aberrant $\mathrm{Ca}^{2+}$ responses induced by various chemical or mechanical stimuli. For example, some primary and immortalised ADPKD cyst-derived cells displayed almost no $\mathrm{Ca}^{2+}$ signal compared to normal kidney cells in response to fluid flow, though the role of PC1 and PC2 in this process remains unclear [13, 19]. It should be noted that the type of mutation in PC1 likely matters. A mutation that only affects ciliary PC1 localisation might imply that PC1 is still functioning at other subcellular locations. Specific mutations could influence $\mathrm{PC} 1$ expression at the plasma membrane and/or the ER and subsequently alter $\mathrm{Ca}^{2+}$ signalling through regulation of PM- or ER-resident PC2 or other polycystininteracting $\mathrm{Ca}^{2+}$ channels. Examples of such channels are transient receptor potential channels TRPC1, 3, 4 and 7 [84-86]; the L-type $\mathrm{Ca}^{2+}$ channels [87]; inositol 1,4,5-trisphosphate receptors $[38,88-91]$; and ryanodine receptors [92].

In addition to the alterations in stimulated $\mathrm{Ca}^{2+}$ signals, basal $\mathrm{Ca}^{2+}$ homeostasis is often altered in ADPKD models, as was the case in the $P K D 1^{+/}$mouse model [93]. Primary cultures of cells derived from three ADPKD kidneys displayed ca. $20 \mathrm{nM}$ lower basal cytosolic $\left[\mathrm{Ca}^{2+}\right]$ compared to cells from three normal kidneys [94]. Interestingly, a similar difference of $20 \mathrm{nM}$ was twice observed in cystic and noncystic cells of the same kidneys that were removed from patients due to abdominal pain, despite normal renal function [94]. However, in another study, basal cytosolic $\left[\mathrm{Ca}^{2+}\right]$ was similar in an immortalised renal cortical tubular and ADPKD cyst-lining epithelial cell line as well as in normal-looking tubules and cystic tubules from three different ADPKD kidneys [13]. The reason for this discrepancy is unclear, as is the functional significance of a $20-\mathrm{nM}$ reduction in basal $\left[\mathrm{Ca}^{2+}\right]$. Interestingly, ER $\left[\mathrm{Ca}^{2+}\right]$ is also lowered in primary cyst-lining epithelial cells from an ADPKD patient with the PC1 p.L2433del mutation (PKD 10-27-98, Table 1) [19]. The reason for the observed changes remain unclear and could involve (a combination of) alterations in $\mathrm{Ca}^{2+}$-pump activity [93], $\mathrm{Ca}^{2+}$-buffering capacity, $\mathrm{Ca}^{2+}$ leak rates $[38,95]$ and intracellular $\mathrm{Ca}^{2+}$ release mechanisms [38, 84, 86-92].

How much these alterations in $\mathrm{Ca}^{2+}$ signalling may contribute to ADPKD disease progression remains a major question. Since PC2 is primarily a $\mathrm{Ca}^{2+}$ channel, it is suggested that the loss of ciliary $\mathrm{Ca}^{2+}$ responses is the primary trigger, leading to increased cAMP levels, increased cell proliferation and finally cystogenesis (discussed more in detail below) [96].

In conclusion, it seems clear that altered $\mathrm{Ca}^{2+}$ homeostasis, dynamics and machinery is an attribute of cyst-forming cells in ADPKD. However, many details are lacking regarding the exact players in the process and the consequences of their malfunctioning.

\section{A distinct CAMP responsiveness in ADPKD}

Increased cAMP is another hallmark of ADPKD and might be the direct cause of proliferation and anion secretion [5]. The first available ADPKD treatment, the AVPR2 antagonist tolvaptan, blocks cAMP increase (in response to AVP) in collecting ducts and thereby highlights the key role of cAMP in cyst growth.

Upon addition of cAMP-generating agonists like IBMX, prostaglandin E2 (PGE2) or forskolin, enhanced proliferation in primary cystic cells and cell lines derived from nephrectomies was observed [16, 81, 97-99], indicating a phenotypic switch to a cAMP-stimulatory proliferative response. These compounds also stimulated fluid secretion [100] and cyst formation of cyst-derived cells in a 3D matrix (see below) [28, 81].

Cystic fluid itself can stimulate the production of cAMP and subsequent proliferation in both animal-derived cell lines and human-derived primary cells [98, 101-103]. From this cystic fluid, a lipid compound was identified in 15 out of 18 patients as being a 'forskolin-like' molecule [104]. However, the production site of this molecule remains unclear.

Lower cytosolic $\mathrm{Ca}^{2+}$ levels could contribute to a distinct cAMP response in PKD-derived cell lines. $\mathrm{Ca}^{2+}$ channel blockers verapamil and nifedipine increased the cell proliferation rate in both cystic and non-cystic cells obtained from different regions from the same kidneys, especially when combined with cAMP increase [94]. Compounds increasing basal cytosolic $\left[\mathrm{Ca}^{2+}\right]$, such as the L-type $\mathrm{Ca}^{2+}$ channel agonist Bay K8644 and the $\mathrm{Ca}^{2+}$ ionophore A23187, induced opposite effects. In addition, Bay K8644 inhibited forskolininduced cyst formation in cystic cells. This is in line with results in non-orthologous rodent models, where increased or decreased cystic disease was observed upon administration of verapamil or the calcimimetic R-568, respectively [105, 
106]. Interestingly, an increase of [cAMP] alone already increased proliferation in cystic cells but reduced proliferation in non-cystic cells, suggesting that the difference in basal cytosolic $\left[\mathrm{Ca}^{2+}\right]$ in cystic versus non-cystic cells determines whether cAMP stimulates or inhibits proliferation [94]. However, it cannot be excluded that other alterations in cystic cells may also play a role in establishing the proliferative and cystogenic characteristics of cystic cells in ADPKD.

While several rodent models of cystic disease show highly increased levels of cAMP in the kidney and urine [107], basal cAMP levels in human-derived cells are seldom reported. Pinto et al. observed higher basal cAMP levels in cysticderived primary cells compared to normal human kidney cells $(1.1 \pm 0.1$ vs. $0.7 \pm 0.1 \mathrm{pmol} /$ monolayer $)$, measured with a cAMP enzyme immunoassay. They attribute these observations to a (weak) upregulation of $\mathrm{Ca}^{2+}$-regulated adenylate cyclases (AC5 and AC6) and a downregulation of $\mathrm{Ca}^{2+}$-regulated phosphodiesterases $[43,108]$. Furthermore, adenylate cyclase activity itself could be induced by Gi-signalling inhibition [5].

High levels of circulating AVP have been associated with ADPKD [107]. Furthermore, AVPR2 mRNA levels were 1.4fold higher in primary cystic-derived cells compared to normal kidney controls [108]. AVP and its more stable AVPR2specific analogue desmopressin (DDAVP) were able to increase cellular cAMP levels and enhance proliferation in primary cystic cells and cell lines, but not in controls $[16,44,81$, 97], which was inhibited by pre-treatment with tolvaptan, but not in control kidney cells [44]. These results are in line with the results observed in the non-orthologous PCK rat and orthologous PKD1 (Pkd $\left.{ }^{R C / R C}\right)$ and PKD2 (Pkd2 $2^{W S 25 /-}$ ) ADPKD mouse models [107]. Remarkably, Pinto et al. observed a lower response upon AVP addition in cystic-derived cells compared to normal human kidney cells [108]. In contrast, Loghman-Adham et al. did not observe a cAMP response to similar concentrations of AVP in a cell line of distal origin (WT 10-7, Table 1), while control RCTE did mildly respond [12]. Interestingly, cystic cells of proximal origin (WT 9-7, Table 1) did not only show a response to parathyroid hormone (PTH), a known stimulator of proximal tubular cells, but also to AVP, which did not stimulate control cell lines of tubular origin [12].

In conclusion, cAMP-mediated signalling seems to be different in PKD-derived cystic cells and cell lines compared to controls. Furthermore, several factors do contribute to higher cAMP levels observed in diseased kidneys and cystic-derived cells. The mechanism remains, however, unclear and might be heterogeneous.

\section{Altered mTOR metabolism in ADPKD}

Increased mTOR activity has been observed in ADPKD cell and animal models [6]. Accordingly, mTOR inhibitors showed a reduction of cyst growth and prevented kidney function loss in several rodent models. Unfortunately, this strategy was unsuccessful in clinical trials [109-111]. Apart from methodological issues with these studies, translation between mouse and human kidney is not self-evident. For example, some of these mice models develop cysts due to alterations in non-orthologous genes of $P K D 1$ or $P K D 2$. Furthermore, in most orthologous models, a conditional homozygous knockout of $p k d 1$ results into a fast progressing disease with a fast simultaneous development of multiple cysts. This in contrast to human ADPKD, characterised by a development over decades [72]. Thirdly, an upregulated mTOR activity was only detected in cell lines derived from patients with mutations in $P K D 1$ or a $P K D 1 \mathrm{KD}$ and not in cell lines with affected PC2 expression [22]. Finally, typical compounds that inhibit mTOR activity are notoriously unspecific.

It was also shown that rapamycin and metformin could reduce mTOR activity synergistically in $P K D 1 \mathrm{KD}$ cell lines, which could be useful for further trials. A reduction in mTOR activity was also observed upon cAMP and mTOR signalling inhibition by A3-receptor antagonist Cl-IB-MECA together with rapamycin in WT 9-7 and WT 9-12 cell lines (Table 1) [112]. However, reduction of proliferation was only observed after sequential administration. The latter results suggest that inhibition of mTOR activity alone might not be sufficient to inhibit proliferation. Additionally, berberine slows down proliferation of the same cell lines, by also inhibiting ERK and S6 phosphorylation [113].

In conclusion, the contribution of a reduction of mTOR on ADPKD should be evaluated more in depth, and synergistic treatments targeting multiple pathways involved in ADPKD might be more effective. Furthermore, genotyping might be necessary for future clinical trials, as only $P K D 1 \mathrm{KD}$ or mutant cell lines showed an altered mTOR metabolism [22].

\section{In vitro cyst formation in ADPKD: a valuable tool for drug development?}

As the main goal in battling ADPKD is to find therapies preventing cyst formation, the development of a reproducible cystogenesis assay seems crucial. Several cyst lining-derived primary cells and cell lines have been shown to form cysts, while controls did not, or to a lesser extent (Table 1) [21, 34, 81]. 8-Br-cAMP, forskolin, IBMX, transferrin, dexamethasone, insulin and triiodothyronine all induced cyst growth and/or fluid excretion in cultured cysts from primary ADPKD-derived cells $[28,81]$. Tolvaptan or a STAT5 inhibitor resulted in decreased cyst growth in vitro with primary cells and the OX161 cell line, respectively [17, 44]. Interestingly, also miR-17 downregulation was found to reduce cyst growth originating from cell lines (and in animal models), indicating that such an assay is useful to find novel 
approaches to inhibit cyst formation [32]. Unfortunately, no comparison with control cell lines was included in these experiments. Moreover, some non-ADPKD-derived cells tend to form cysts in vitro.

However, the studied cell lines were derived from endstage kidneys, and the specific pathways that contribute to cyst initiation remain unclear. Therefore, it would be of prime interest to study cell signalling and the effect of various compounds in 'early stage' cell models or genetically engineered models as for example organoids from ADPKD $P K D 1^{-/-}$ hPSCs, which were described to form cyst-like structures alongside tubular organoids, while controls did not $[26,36]$. Moreover, this model suggested that this cystic phenotype is not fully penetrant, as cyst formation was only observed in a minority of kidney organoids. These results are in line with the in vivo situation. Hence, they form a proof of concept for the use of kidney organoids as valid models.

In general, kidney organoids form an interesting starting point to model ciliopathies. Recently, Forbes et al. managed to generate kidney organoids from iPSCs derived from a nephronophthisis-related ciliopathy patient with compoundheterozygous mutations in IFT140 [114]. Cilia were shorter in organoid tubules derived from patient iPSCs, compared to iPSCs where the germline mutation was corrected using CRIPSR-Cas9 technology.

\section{Conclusion}

Human-based ADPKD cell models could be valuable tools in ADPKD research to increase the understanding of the molecular mechanisms behind the disease and for the development of assays for drug discovery. Nevertheless, several concerns have to be taken into account (Fig. 2): First, most published cell models are derived from end-stage kidneys, which do not reflect disease initiation. The inclusion of cells derived from patients exhibiting signs of early disease or genetically engineered cell lines is crucial. Second, comparison of different human-derived cell lines requires identical immortalisation procedures, similar oncogene expression levels and similar segmental origin. Additionally, epithelial cells tend to lose or change a fraction of their characteristics when kept in culture. Therefore, thorough characterisation, inclusion of adequate controls and evaluation of multiple humanderived models are mandatory to obtain reliable results.
Fig. 2 Considerations and strategies for experiments with human-derived cell lines, concerning genetics and epigenetics, transformation, epithelial and segmental origin, culturing conditions and the observed phenotype. $=$ similar + positive; - negative

\begin{tabular}{|c|c|c|}
\hline & CONSIDERATIONS & STRATEGY \\
\hline $\begin{array}{l}\text { genetics and } \\
\text { epigenetics }\end{array}$ & $\begin{array}{l}\circ \text { background } \\
\circ P K D \text { mutations } \\
\circ \text { gender/age } \\
\circ \text { end stage disease }\end{array}$ & $\begin{array}{l}\text { o multiple donors } \\
\text { o mutation sequencing } \\
\text { o matched controls } \\
\text { o early stage disease }\end{array}$ \\
\hline transformation & $\begin{array}{l}\text { oncogene/ } \\
\text { reprogramming } \\
\text { gene: interference } \\
\text { with } \neq \text { pathways } \\
\text { integrating vector: } \\
\text { effect integration sites }\end{array}$ & $\begin{array}{l}\text { O same oncogene } \\
\text { o similar expression levels } \\
\text { o inactivate/flox out } \\
\text { oncogene } \\
\text { o same vector backbone }\end{array}$ \\
\hline $\begin{array}{r}\text { nephron segment and } \\
\text { epithelial origin }\end{array}$ & $\begin{array}{l}\circ \neq \text { kidney segments } \\
\text { with } \neq \text { properties } \\
\text { non-epithelial origin }\end{array}$ & $\begin{array}{l}\text { identification using a } \\
\text { panel of }+/- \text { markers }\end{array}$ \\
\hline culturing conditions & $\begin{array}{l}\text { plastic, media, } \\
\text { coating, matrix, ... } \\
\text { spontaneous cyst } \\
\text { formation 3D }\end{array}$ & $\begin{array}{l}\text { oxperimental conditions } \\
\text { in parallel } \\
\text { take along appropriate } \\
\text { non-cystic controls }\end{array}$ \\
\hline phenotype & $\begin{array}{l}\text { o specific effect of } \\
\text { mutation }\end{array}$ & $\begin{array}{l}\text { introduce/correct } \\
\text { mutation using gene } \\
\text { editing }\end{array}$ \\
\hline
\end{tabular}


Characterisation should minimally include sequencing to confirm a disease-causing mutation, the detection of a panel of markers for epithelial origin and comparison of expression levels of the introduced oncogene or reprogramming gene. Determination of the zygosity of the mutation would also be of interest. An overview of recommendations for the generation and use of ADPKD-derived cell lines is given in Fig. 2.

Yet, these cell-based models allow new experimental approaches. For instance, backcomplementing PKD1/PKD2 KO or KD kidney cell lines with $P K D 1 / P K D 2$ containing known patient mutations or the direct introduction of precise patient mutations and corrections using gene editing would be valuable strategies to study the mechanisms of disease in ADPKD. This latter technology would also enable to edit mutations in modifier genes to identify pathways contributing to cyst formation. The effect of PC1 dosage could be further studied by differential PKD1 KD (or $P K D 1$ backcomplementation) resulting in distinct $\mathrm{PCl}$ expression levels. Finally, as cysts are multicellular structures, 3Dculturing and kidney-based organoids offer new perspectives for ADPKD research, particularly by allowing the development of a cyst-forming assay. These assays can be used for in vitro drug screening, as shown with tolvaptan for example [44]. Furthermore, these assays can contribute to a thorough understanding of the contribution of specific pathways or mutations to cyst formation, especially in combination with gene editing $[36,114]$.

In conclusion, this review demonstrates the importance of a thorough validation and an appropriate experimental design when using human-derived cell models for ADPKD research (Fig. 2). Nonetheless, when appropriately exploited, these models can be of great value, (complementary with animal studies) to give fundamental insights into ADPKD. Considering that the key hallmark of ADPKD, cyst formation by a fraction of epithelial cells, is still incompletely understood, the development of reliable patientspecific cell models remains crucial to the field.

\section{Key summary points}

1. Human-derived cell models are an essential tool to study ADPKD.

2. Results in cell lines derived from patients can be influenced by the mutation, the disease stage, the immortalisation procedure, nephron origin and patient background.

3. Cyst-initiating factors can be studied using humanderived cell lines with $P K D 1 / P K D 2 \mathrm{KO} / \mathrm{KD}$ and non-cystic patient-derived cell lines.

4. Alterations in mTOR activity, cAMP response and $\mathrm{Ca}^{2+}$ homeostasis can be observed in cyst-derived cells and cell lines.

5. In vitro cyst formation could be a valuable screening tool.

\section{Multiple choice questions (answers are provided following the reference list)}

1. Which cell line is not a published human ADPKDderived cell model until now?

a) Cell lines from ADPKD patients obtained from urine

b) Cell lines from ADPKD patients obtained from nephrectomies

c) Cell lines from ADPKD patients obtained from skin, reprogrammed to hPSCs

d) Cell lines with ADPKD patient-derived PKD2 mutations, inserted using CRISPR

e) Cell lines with $P K D 2$ knockout or knockdown

2. Which statement is true about the immortalisation procedure?

a) If cells are immortalised using SV40 LT, it does not matter with which vector they were immortalised.

b) SV40 LT can stimulate proliferation through suppression of the tumour suppressor gene p53 (amongst interference with other pathways).

c) Cells immortalised with SV40 LT will never become senescent.

d) Immortalisation with hTERT alone does not affect cell properties.

e) HK-2 cells and RCTEs are immortalised with the same constructs and, hence, are interchangeable.

3. Which markers are expected on cell lines from proximal tubular origin?

a) AQP1, ECAD, MDR1, AQP2

b) AQP1, NCAD, MDR1, AQP2

c) AQP1, NCAD, MDR1, NCC

d) AQP2, ECAD, MDR1, NHE3

e) AQP1, NCAD, MDR1, NHE3

4. What has not been described in ADPKD patient-derived cells?

a) Decreased ciliary $\left[\mathrm{Ca}^{2+}\right]$-influx upon shear stress in several cystic-derived cell lines

b) A decrease in [cAMP] upon tolvaptan administration in several cystic-derived cell lines

c) An increase in mTOR activity in human proximal tubularderived cell lines with $P K D 2 K D$

d) cAMP-generating agonists stimulate proliferation in several cystic-derived cell lines

e) Full-length PC1 expression is decreased in several cysticderived cell lines 
5. Which statement is not true about in vitro cyst formation?

a) IBMX slows down cyst growth of the OX161 cell line.

b) STAT5 inhibitors slow down cyst growth of the OX161 cell line.

c) Tolvapatan slows down cyst growth of primary cystic cells.

d) Forskolin stimulates cyst growth of cystic primary cells.

e) miR-17 downregulation reduces cyst growth of cyst-derived primary cells.

Funding information Our research is supported by VLAIO and the Clinical Research Fund of UZ Leuven.

\section{Compliance with ethical standards}

Conflict of interest The authors declare that they have no conflict of interest.

\section{References}

1. Cornec-Le Gall E, Torres VE, Harris PC (2017) Genetic complexity of autosomal dominant polycystic kidney and liver diseases. J Am Soc Nephrol. https://doi.org/10.1681/ASN.2017050483

2. Gabow PA, Johnson AM, Kaehny WD, Kimberling WJ, Lezotte DC, Duley IT, Jones RH (1992) Factors affecting the progression of renal disease in autosomal-dominant polycystic kidney disease. Kidney Int 41:1311-1319

3. Cornec-Le Gall E, Audrezet MP, Chen JM, Hourmant M, Morin MP, Perrichot R, Charasse C, Whebe B, Renaudineau E, Jousset P, Guillodo MP, Grall-Jezequel A, Saliou P, Ferec C, Le Meur Y (2013) Type of PKD1 mutation influences renal outcome in ADPKD. J Am Soc Nephrol 24:1006-1013. https://doi.org/10. 1681/ASN.2012070650

4. Hanaoka K, Qian F, Boletta A, Bhunia AK, Piontek K, Tsiokas L, Sukhatme VP, Guggino WB, Germino GG (2000) Co-assembly of polycystin-1 and -2 produces unique cation-permeable currents. Nature 408:990-994. https://doi.org/10.1038/35050128

5. Calvet JP (2015) The role of calcium and cyclic AMP in PKD. In: Li X (ed) Polycystic kidney disease. Codon Publications, Brisbane (AU). https://doi.org/10.15586/codon.pkd.2015.ch8

6. Ibraghimov-Beskrovnaya O, Natoli TA (2011) mTOR signaling in polycystic kidney disease. Trends Mol Med 17:625-633. https:// doi.org/10.1016/j.molmed.2011.06.003

7. Torres VE, Chapman AB, Devuyst O, Gansevoort RT, Grantham JJ, Higashihara E, Perrone RD, Krasa HB, Ouyang J, Czerwiec FS (2012) Tolvaptan in patients with autosomal dominant polycystic kidney disease. N Engl J Med 367:2407-2418. https://doi.org/10. 1056/NEJMoa1205511

8. Yu ASL, El-Ters M, Winklhofer FT (2015) Clinical trials in autosomal dominant polycystic kidney disease. In: Li X (ed) Polycystic kidney disease. Codon Publications, Brisbane (AU). https://doi.org/10.15586/codon.pkd.2015.ch6

9. Song X, Di Giovanni V, He N, Wang K, Ingram A, Rosenblum ND, Pei Y (2009) Systems biology of autosomal dominant polycystic kidney disease (ADPKD): computational identification of gene expression pathways and integrated regulatory networks. Hum Mol Genet 18:2328-2343. https://doi.org/10.1093/hmg/ ddp165
10. Grantham JJ (2009) Autosomal dominant polycystic kidney disease. Ann Transplant 14:86-90

11. Wilson PD, Schrier RW, Breckon RD, Gabow PA (1986) A new method for studying human polycystic kidney disease epithelia in culture. Kidney Int 30:371-378

12. Loghman-Adham M, Nauli SM, Soto CE, Kariuki B, Zhou J (2003) Immortalized epithelial cells from human autosomal dominant polycystic kidney cysts. Am J Physiol Renal Physiol 285: F397-F412. https://doi.org/10.1152/ajprenal.00310.2002

13. Nauli SM, Rossetti S, Kolb RJ, Alenghat FJ, Consugar MB, Harris PC, Ingber DE, Loghman-Adham M, Zhou J (2006) Loss of polycystin-1 in human cyst-lining epithelia leads to ciliary dysfunction. J Am Soc Nephrol 17:1015-1025. https://doi.org/10. 1681/ASN.2005080830

14. Rossetti S, Chauveau D, Walker D, Saggar-Malik A, Winearls CG, Torres VE, Harris PC (2002) A complete mutation screen of the ADPKD genes by DHPLC. Kidney Int 61(5):1588-1599. https://doi.org/10.1046/j.1523-1755.2002.00326.x

15. Streets AJ, Newby LJ, O'Hare MJ, Bukanov NO, IbraghimovBeskrovnaya O, Ong AC (2003) Functional analysis of PKD1 transgenic lines reveals a direct role for polycystin-1 in mediating cell-cell adhesion. J Am Soc Nephrol 14(7):1804-1815

16. Parker E, Newby LJ, Sharpe CC, Rossetti S, Streets AJ, Harris PC, O'Hare MJ, Ong AC (2007) Hyperproliferation of PKD1 cystic cells is induced by insulin-like growth factor-1 activation of the Ras/Raf signalling system. Kidney Int 72(2):157-165. https://doi. org/10.1038/sj.ki.5002229

17. Fragiadaki M, Lannoy M, Themanns M, Maurer B, Leonhard WN, Peters DJ, Moriggl R, Ong AC (2017) STAT5 drives abnormal proliferation in autosomal dominant polycystic kidney disease. Kidney Int 91(3):575-586. https://doi.org/10.1016/j.kint. 2016.10.039

18. Streets AJ, Magayr TA, Huang L, Vergoz L, Rossetti S, Simms RJ, Harris PC, Peters DJ, Ong AC (2017) Parallel microarray profiling identifies ErbB4 as a determinant of cyst growth in ADPKD and a prognostic biomarker for disease progression. Am J Physiol Renal Physiol 312(4):F577-F588. https://doi.org/10.1152/ajprenal. 00607.2016

19. Xu C, Rossetti S, Jiang L, Harris PC, Brown-Glaberman U, Wandinger-Ness A, Bacallao R, Alper SL (2007) Human ADPKD primary cyst epithelial cells with a novel, single codon deletion in the PKD1 gene exhibit defective ciliary polycystin localization and loss of flow-induced $\mathrm{Ca} 2+$ signaling. Am J Physiol Renal Physiol 292(3):F930-F945. https://doi.org/10. 1152/ajprenal.00285.2006

20. Xu C, Shmukler BE, Nishimura K, Kaczmarek E, Rossetti S, Harris PC, Wandinger-Ness A, Bacallao RL, Alper SL (2009) Attenuated, flow-induced ATP release contributes to absence of flow-sensitive, purinergic Cai2+ signaling in human ADPKD cyst epithelial cells. Am J Physiol Renal Physiol 296(6):F1464-F1476. https://doi.org/10.1152/ajprenal.90542.2008

21. Herbert BS, Grimes BR, Xu WM, Werner M, Ward C, Rossetti S, Harris P, Bello-Reuss E, Ward HH, Miller C, Gattone VH 2nd, Phillips CL, Wandinger-Ness A, Bacallao RL (2013) A telomerase immortalized human proximal tubule cell line with a truncation mutation (Q4004X) in polycystin-1. PLoS One 8(1):e55191. https://doi.org/10.1371/journal.pone.0055191

22. Mekahli D, Decuypere JP, Sammels E, Welkenhuyzen K, Schoeber J, Audrezet MP, Corvelyn A, Dechenes G, Ong AC, Wilmer MJ, van den Heuvel L, Bultynck G, Parys JB, Missiaen L, Levtchenko E, De Smedt H (2014) Polycystin-1 but not polycystin-2 deficiency causes upregulation of the mTOR pathway and can be synergistically targeted with rapamycin and metformin. Pflugers Arch 466(8):1591-1604. https://doi.org/10. 1007/s00424-013-1394-x 
23. Wilmer MJ, Saleem MA, Masereeuw R, Ni L, van der Velden TJ, Russel FG, Mathieson PW, Monnens LA, van den Heuvel LP, Levtchenko EN (2010) Novel conditionally immortalized human proximal tubule cell line expressing functional influx and efflux transporters. Cell Tissue Res 339(2):449-457. https://doi.org/10. 1007/s00441-009-0882-y

24. Wilmer MJ, Kluijtmans LA, van der Velden TJ, Willems PH, Scheffer PG, Masereeuw R, Monnens LA, van den Heuvel LP, Levtchenko EN (2011) Cysteamine restores glutathione redox status in cultured cystinotic proximal tubular epithelial cells. Biochim Biophys Acta 1812(6):643-651. https://doi.org/10. 1016/j.bbadis.2011.02.010

25. Freedman BS, Lam AQ, Sundsbak JL, Iatrino R, Su X, Koon SJ, Wu M, Daheron L, Harris PC, Zhou J, Bonventre JV (2013) Reduced ciliary polycystin-2 in induced pluripotent stem cells from polycystic kidney disease patients with PKD1 mutations. J Am Soc Nephrol 24(10):1571-1586. https://doi.org/10.1681/ ASN.2012111089

26. Freedman BS (2015) Modeling kidney disease with iPS cells. Biomark Insights 10(Suppl 1):153-169. https://doi.org/10.4137/ BMI.S20054

27. Carone FA, Nakamura S, Schumacher BS, Punyarit P, Bauer KD (1989) Cyst-derived cells do not exhibit accelerated growth or features of transformed cells in vitro. Kidney Int 35(6):1351-1357

28. Wallace DP, Grantham JJ, Sullivan LP (1996) Chloride and fluid secretion by cultured human polycystic kidney cells. Kidney Int 50(4):1327-1336

29. Charron AJ, Nakamura S, Bacallao R, Wandinger-Ness A (2000) Compromised cytoarchitecture and polarized trafficking in autosomal dominant polycystic kidney disease cells. J Cell Biol 149(1):111-124. https://doi.org/10.1083/jcb.149.1.111

30. Nauli SM, Alenghat FJ, Luo Y, Williams E, Vassilev P, Li X, Elia AE, Lu W, Brown EM, Quinn SJ, Ingber DE, Zhou J (2003) Polycystins 1 and 2 mediate mechanosensation in the primary cilium of kidney cells. Nat Genet 33(2):129-137. https://doi.org/ 10.1038/ng1076

31. de Almeida RM, Clendenon SG, Richards WG, Boedigheimer M, Damore M, Rossetti S, Harris PC, Herbert BS, Xu WM, Wandinger-Ness A, Ward HH, Glazier JA, Bacallao RL (2016) Transcriptome analysis reveals manifold mechanisms of cyst development in ADPKD. Hum Genomics 10(1):37. https://doi.org/ 10.1186/s40246-016-0095-x

32. Hajarnis S, Lakhia R, Yheskel M, Williams D, Sorourian M, Liu XQ, Aboudehen K, Zhang SR, Kersjes K, Galasso R, Li J, Kaimal V, Lockton S, Davis S, Flaten A, Johnson JA, Holland WL, Kusminski CM, Scherer PE, Harris PC, Trudel M, Wallace DP, Igarashi P, Lee EC, Androsavich JR, Patel V (2017) MicroRNA17 family promotes polycystic kidney disease progression through modulation of mitochondrial metabolism. Nat Commun 8. doi: Artn 14395. https://doi.org/10.1038/Ncomms 14395

33. Ben-Dov IZ, Tan YC, Morozov P, Wilson PD, Rennert H, Blumenfeld JD, Tuschl T (2014) Urine microRNA as potential biomarkers of autosomal dominant polycystic kidney disease progression: description of miRNA profiles at baseline. PLoS ONE 9 (1). doi: ARTN e86856. https://doi.org/10.1371/journal.pone. 0086856

34. Lakhia R, Hajarnis S, Williams D, Aboudehen K, Yheskel M, Xing C, Hatley ME, Torres VE, Wallace DP, Patel V (2016) MicroRNA-21 aggravates cyst growth in a model of polycystic kidney disease. J Am Soc Nephrol 27(8):2319-2330. https://doi. org/10.1681/Asn.2015060634

35. Huang J, Zhou S, Niu X, Hu B, Li Q, Zhang F, Zhang X, Cai X, Lou Y, Liu F, Xu C, Wang Y (2017) Generation of special autosomal dominant polycystic kidney disease iPSCs with the capability of functional kidney-like cell differentiation. Stem Cell Res Ther 8(1):196. https://doi.org/10.1186/s13287-017-0645-8
36. Freedman BS, Brooks CR, Lam AQ, Fu H, Morizane R, Agrawal V, Saad AF, Li MK, Hughes MR, Werff RV, Peters DT, Lu J, Baccei A, Siedlecki AM, Valerius MT, Musunuru K, McNagny KM, Steinman TI, Zhou J, Lerou PH, Bonventre JV (2015) Modelling kidney disease with CRISPR-mutant kidney organoids derived from human pluripotent epiblast spheroids. Nat Commun 6:8715. https://doi.org/10.1038/ncomms 9715

37. Huang CY, Ho MC, Lee JJ, Hwang DY, Ko HW, Cheng YC, Hsu YH, Lu HE, Chen HC, Hsieh PCH (2017) Generation of induced pluripotent stem cells derived from an autosomal dominant polycystic kidney disease patient with a p.Ser1457fs mutation in PKD1. Stem Cell Res 24:139-143. https://doi.org/10.1016/j.scr. 2017.09.004

38. Mekahli D, Sammels E, Luyten T, Welkenhuyzen K, van den Heuvel LP, Levtchenko EN, Gijsbers R, Bultynck G, Parys JB, De Smedt H, Missiaen L (2012) Polycystin-1 and polycystin-2 are both required to amplify inositol-trisphosphate-induced $\mathrm{Ca} 2+$ release. Cell Calcium 51(6):452-458. https://doi.org/10.1016/j.ceca. 2012.03.002

39. Battini L, Fedorova E, Macip S, Li X, Wilson PD, Gusella GL (2006) Stable knockdown of polycystin-1 confers integrinalpha2beta1-mediated anoikis resistance. J Am Soc Nephrol 17(11):3049-3058. https://doi.org/10.1681/ASN.2006030234

40. Subramanian B, Ko WC, Yadav V, DesRochers TM, Perrone RD, Zhou J, Kaplan DL (2012) The regulation of cystogenesis in a tissue engineered kidney disease system by abnormal matrix interactions. Biomaterials 33(33):8383-8394. https://doi.org/10. 1016/j.biomaterials.2012.08.020

41. Wang E, Hsieh-Li HM, Chiou YY, Chien YL, Ho HH, Chin HJ, Wang CK, Liang SC, Jiang ST (2010) Progressive renal distortion by multiple cysts in transgenic mice expressing artificial microRNAs against Pkd1. J Pathol 222:238-248. https://doi.org/ 10.1002/path.2765

42. Woo YM, Shin Y, Hwang JA, Hwang YH, Lee S, Park EY, Kong HK, Park HC, Lee YS, Park JH (2015) Epigenetic silencing of the MUPCDH gene as a possible prognostic biomarker for cyst growth in ADPKD. Sci Rep 5:15238. https://doi.org/10.1038/ srep15238

43. Pinto CS, Raman A, Reif GA, Magenheimer BS, White C, Calvet JP, Wallace DP (2016) Phosphodiesterase isoform regulation of cell proliferation and fluid secretion in autosomal dominant polycystic kidney disease. J Am Soc Nephrol 27(4):1124-1134. https://doi.org/10.1681/ASN.2015010047

44. Reif GA, Yamaguchi T, Nivens E, Fujiki H, Pinto CS, Wallace DP (2011) Tolvaptan inhibits ERK-dependent cell proliferation, $\mathrm{Cl}(-)$ secretion, and in vitro cyst growth of human ADPKD cells stimulated by vasopressin. Am J Physiol Renal Physiol 301(5):F1005F1013. https://doi.org/10.1152/ajprenal.00243.2011

45. Ahuja D, Saenz-Robles MT, Pipas JM (2005) SV40 large T antigen targets multiple cellular pathways to elicit cellular transformation. Oncogene 24:7729-7745. https://doi.org/10.1038/sj.onc. 1209046

46. Arndt GM, MacKenzie KL (2016) New prospects for targeting telomerase beyond the telomere. Nat Rev Cancer 16(8):508524. https://doi.org/10.1038/nrc.2016.55

47. MacKay K, Striker LJ, Pinkert CA, Brinster RL, Striker GE (1987) Glomerulosclerosis and renal cysts in mice transgenic for the early region of SV40. Kidney Int 32(6):827-837

48. Mckay RDG, Jat PS, Lamazan G (1993) Method for manipulation of the cell types of eukaryotes. Google Patents

49. Loeber G, Tevethia MJ, Schwedes JF, Tegtmeyer P (1989) Temperature-sensitive mutants identify crucial structural regions of simian virus 40 large $T$ antigen. J Virol 63:4426-4430

50. Demeulemeester J, De Rijck J, Gijsbers R, Debyser Z (2015) Retroviral integration: site matters: mechanisms and consequences 
of retroviral integration site selection. Bioessays 37(11):12021214. https://doi.org/10.1002/bies.201500051

51. Liu Z, Li Q, Li K, Chen L, Li W, Hou M, Liu T, Yang J, Lindvall C, Bjorkholm M, Jia J, Xu D (2013) Telomerase reverse transcriptase promotes epithelial-mesenchymal transition and stem cell-like traits in cancer cells. Oncogene 32(36):4203-4213. https://doi.org/ 10.1038/onc.2012.441

52. Nouwen EJ, Dauwe S, van der Biest I, De Broe ME (1993) Stageand segment-specific expression of cell-adhesion molecules $\mathrm{N}$ CAM, A-CAM, and L-CAM in the kidney. Kidney Int 44(1): $147-158$

53. Knepper MA, Brooks HL (2001) Regulation of the sodium transporters NHE3, NKCC2 and NCC in the kidney. Curr Opin Nephrol Hypertens 10(5):655-659

54. Yamada H, Yamazaki S, Moriyama N, Hara C, Horita S, Enomoto Y, Kudo A, Kawakami H, Tanaka Y, Fujita T, Seki G (2003) Localization of NBC-1 variants in human kidney and renal cell carcinoma. Biochem Biophys Res Commun 310(4):1213-1218

55. Damkier HH, Nielsen S, Praetorius J (2007) Molecular expression of SLC4-derived Na+-dependent anion transporters in selected human tissues. Am J Physiol Regul Integr Comp Physiol 293(5): R2136-R2146. https://doi.org/10.1152/ajpregu.00356.2007

56. Motohashi H, Sakurai Y, Saito H, Masuda S, Urakami Y, Goto M, Fukatsu A, Ogawa O, Inui K (2002) Gene expression levels and immunolocalization of organic ion transporters in the human kidney. J Am Soc Nephrol 13(4):866-874

57. Ekaratanawong S, Anzai N, Jutabha P, Miyazaki H, Noshiro R, Takeda M, Kanai Y, Sophasan S, Endou H (2004) Human organic anion transporter 4 is a renal apical organic anion/dicarboxylate exchanger in the proximal tubules. J Pharmacol Sci 94(3):297304

58. Thiebaut F, Tsuruo T, Hamada H, Gottesman MM, Pastan I, Willingham MC (1987) Cellular localization of the multidrugresistance gene product P-glycoprotein in normal human tissues. Proc Natl Acad Sci U S A 84(21):7735-7738

59. Maunsbach AB, Marples D, Chin E, Ning G, Bondy C, Agre P, Nielsen S (1997) Aquaporin-1 water channel expression in human kidney. J Am Soc Nephrol 8(1):1-14

60. van Aubel RA, Smeets PH, Peters JG, Bindels RJ, Russel FG (2002) The MRP4/ABCC4 gene encodes a novel apical organic anion transporter in human kidney proximal tubules: putative efflux pump for urinary cAMP and cGMP. J Am Soc Nephrol 13(3): 595-603

61. Cordon-Cardo C, O'Brien JP, Boccia J, Casals D, Bertino JR, Melamed MR (1990) Expression of the multidrug resistance gene product (P-glycoprotein) in human normal and tumor tissues. J Histochem Cytochem 38(9):1277-1287. https://doi.org/10.1177/ 38.9.1974900

62. Ernest S, Rajaraman S, Megyesi J, Bello-Reuss EN (1997) Expression of MDR1 (multidrug resistance) gene and its protein in normal human kidney. Nephron 77(3):284-289

63. Baer PC, Nockher WA, Haase W, Scherberich JE (1997) Isolation of proximal and distal tubule cells from human kidney by immunomagnetic separation. Technical note. Kidney Int 52(5): $1321-1331$

64. Hennigar RA, Schulte BA, Spicer SS (1985) Heterogeneous distribution of glycoconjugates in human kidney tubules. Anat Rec 211(4):376-390. https://doi.org/10.1002/ar.1092110403

65. Piela-Smith TH, Korn JH (1995) Aminopeptidase N: a constitutive cell-surface protein on human dermal fibroblasts. Cell Immunol 162(1):42-48. https://doi.org/10.1006/cimm.1995.1049

66. Lorkowski G, Zijderhand-Bleekemolen JE, Erdos EG, von Figura K, Hasilik A (1987) Neutral endopeptidase-24.11 (enkephalinase). Biosynthesis and localization in human fibroblasts. Biochem $\mathrm{J}$ 248(2):345-350
67. Olerud JE, Usui ML, Seckin D, Chiu DS, Haycox CL, Song IS, Ansel JC, Bunnett NW (1999) Neutral endopeptidase expression and distribution in human skin and wounds. J Invest Dermatol 112(6):873-881. https://doi.org/10.1046/j.1523-1747.1999. 00596.x

68. Grantham JJ, Geiser JL, Evan AP (1987) Cyst formation and growth in autosomal dominant polycystic kidney disease. Kidney Int 31(5):1145-1152

69. Murata F, Tsuyama S, Suzuki S, Hamada H, Ozawa M, Muramatsu T (1983) Distribution of glycoconjugates in the kidney studied by use of labeled lectins. J Histochem Cytochem 31(1A Suppl):139-144

70. Biner HL, Arpin-Bott MP, Loffing J, Wang X, Knepper M, Hebert SC, Kaissling B (2002) Human cortical distal nephron: distribution of electrolyte and water transport pathways. J Am Soc Nephrol 13(4):836-847

71. Chang MY, A CMO (2017) Targeting new cellular disease pathways in autosomal dominant polycystic kidney disease. Nephrol Dial Transplant. https://doi.org/10.1093/ndt/gfx262

72. Happe H, Peters DJ (2014) Translational research in ADPKD: lessons from animal models. Nat Rev Nephrol 10(10):587-601. https://doi.org/10.1038/nrneph.2014.137

73. Yoder BK, Hou X, Guay-Woodford LM (2002) The polycystic kidney disease proteins, polycystin-1, polycystin-2, polaris, and cystin, are co-localized in renal cilia. J Am Soc Nephrol 13(10): 2508-2516

74. Luyten A, Su X, Gondela S, Chen Y, Rompani S, Takakura A, Zhou J (2010) Aberrant regulation of planar cell polarity in polycystic kidney disease. J Am Soc Nephrol 21(9):1521-1532. https://doi.org/10.1681/ASN.2010010127

75. Patel V, Li L, Cobo-Stark P, Shao X, Somlo S, Lin F, Igarashi P (2008) Acute kidney injury and aberrant planar cell polarity induce cyst formation in mice lacking renal cilia. Hum Mol Genet 17(11):1578-1590. https://doi.org/10.1093/hmg/ddn045

76. Grimm DH, Cai Y, Chauvet V, Rajendran V, Zeltner R, Geng L, Avner ED, Sweeney W, Somlo S, Caplan MJ (2003) Polycystin-1 distribution is modulated by polycystin-2 expression in mammalian cells. J Biol Chem 278(38):36786-36793. https://doi.org/10. 1074/jbc.M306536200

77. Geng L, Okuhara D, Yu Z, Tian X, Cai Y, Shibazaki S, Somlo S (2006) Polycystin-2 traffics to cilia independently of polycystin-1 by using an N-terminal RVxP motif. J Cell Sci 119(Pt 7):13831395. https://doi.org/10.1242/jcs. 02818

78. Chang MY, Parker E, Ibrahim S, Shortland JR, Nahas ME, Haylor JL, Ong AC (2006) Haploinsufficiency of Pkd2 is associated with increased tubular cell proliferation and interstitial fibrosis in two murine Pkd2 models. Nephrol Dial Transplant 21(8):2078-2084. https://doi.org/10.1093/ndt/gfl150

79. Ta MH, Liuwantara D, Rangan GK (2015) Effects of pyrrolidine dithiocarbamate on proliferation and nuclear factor-kappaB activity in autosomal dominant polycystic kidney disease cells. BMC Nephrol 16:212. https://doi.org/10.1186/s12882-015-0193-3

80. Venugopal J, Blanco G (2016) Ouabain enhances ADPKD cell apoptosis via the intrinsic pathway. Front Physiol 7:107. https:// doi.org/10.3389/fphys.2016.00107

81. Hanaoka K, Guggino WB (2000) cAMP regulates cell proliferation and cyst formation in autosomal polycystic kidney disease cells. J Am Soc Nephrol 11(7):1179-1187

82. Gonzalez-Perrett S, Kim K, Ibarra C, Damiano AE, Zotta E, Batelli M, Harris PC, Reisin IL, Arnaout MA, Cantiello HF (2001) Polycystin-2, the protein mutated in autosomal dominant polycystic kidney disease (ADPKD), is a Ca2+-permeable nonselective cation channel. Proc Natl Acad Sci U S A 98(3):11821187

83. Vandorpe DH, Chernova MN, Jiang L, Sellin LK, Wilhelm S, Stuart-Tilley AK, Walz G, Alper SL (2001) The cytoplasmic C- 
terminal fragment of polycystin-1 regulates a Ca2+-permeable cation channel. J Biol Chem 276(6):4093-4101. https://doi.org/ 10.1074/jbc.M006252200

84. Tsiokas L, Arnould T, Zhu C, Kim E, Walz G, Sukhatme VP (1999) Specific association of the gene product of PKD2 with the TRPC1 channel. Proc Natl Acad Sci U S A 96(7):3934-3939

85. Du J, Ding M, Sours-Brothers S, Graham S, Ma R (2008) Mediation of angiotensin II-induced $\mathrm{Ca} 2+$ signaling by polycystin 2 in glomerular mesangial cells. Am J Physiol Renal Physiol 294(4):F909-F918. https://doi.org/10.1152/ajprenal.00606.2007

86. Miyagi K, Kiyonaka S, Yamada K, Miki T, Mori E, Kato K, Numata T, Sawaguchi Y, Numaga T, Kimura T, Kanai Y, Kawano M, Wakamori M, Nomura H, Koni I, Yamagishi M, Mori Y (2009) A pathogenic C terminus-truncated polycystin-2 mutant enhances receptor-activated $\mathrm{Ca} 2+$ entry via association with TRPC3 and TRPC7. J Biol Chem 284(49):34400-34412. https://doi.org/10.1074/jbc.M109.015149

87. Pedrozo Z, Criollo A, Battiprolu PK, Morales CR, ContrerasFerrat A, Fernandez C, Jiang N, Luo X, Caplan MJ, Somlo S, Rothermel BA, Gillette TG, Lavandero S, Hill JA (2015) Polycystin-1 is a cardiomyocyte mechanosensor that governs Ltype Ca2+ channel protein stability. Circulation 131(24):21312142. https://doi.org/10.1161/CIRCULATIONAHA.114.013537

88. Li Y, Wright JM, Qian F, Germino GG, Guggino WB (2005) Polycystin 2 interacts with type I inositol 1,4,5-trisphosphate receptor to modulate intracellular $\mathrm{Ca} 2+$ signaling. J Biol Chem 280(50):41298-41306. https://doi.org/10.1074/jbc.M510082200

89. Li Y, Santoso NG, Yu S, Woodward OM, Qian F, Guggino WB (2009) Polycystin-1 interacts with inositol 1,4,5-trisphosphate receptor to modulate intracellular $\mathrm{Ca} 2+$ signaling with implications for polycystic kidney disease. J Biol Chem 284(52):36431-36441. https://doi.org/10.1074/jbc.M109.068916

90. Sammels E, Devogelaere B, Mekahli D, Bultynck G, Missiaen L, Parys JB, Cai Y, Somlo S, De Smedt H (2010) Polycystin-2 activation by inositol 1,4,5-trisphosphate-induced $\mathrm{Ca} 2+$ release requires its direct association with the inositol 1,4,5-trisphosphate receptor in a signaling microdomain. J Biol Chem 285(24): 18794-18805. https://doi.org/10.1074/jbc.M109.090662

91. Santoso NG, Cebotaru L, Guggino WB (2011) Polycystin-1, 2, and STIM1 interact with IP(3) R to modulate ER Ca release through the PI3K/Akt pathway. Cell Physiol Biochem 27(6): 715-726. https://doi.org/10.1159/000330080

92. Anyatonwu GI, Estrada M, Tian X, Somlo S, Ehrlich BE (2007) Regulation of ryanodine receptor-dependent calcium signaling by polycystin-2. Proc Natl Acad Sci U S A 104(15):6454-6459. https://doi.org/10.1073/pnas.0610324104

93. Morel N, Vandenberg G, Ahrabi AK, Caron N, Desjardins F, Balligand JL, Horie S, Devuyst O (2009) PKD 1 haploinsufficiency is associated with altered vascular reactivity and abnormal calcium signaling in the mouse aorta. Pflugers Arch 457(4):845-856. https://doi.org/10.1007/s00424-008-0561$\mathrm{y}$

94. Yamaguchi T, Hempson SJ, Reif GA, Hedge AM, Wallace DP (2006) Calcium restores a normal proliferation phenotype in human polycystic kidney disease epithelial cells. J Am Soc Nephrol 17(1):178-187. https://doi.org/10.1681/ASN.2005060645

95. Weber KH, Lee EK, Basavanna U, Lindley S, Ziegelstein RC, Germino GG, Sutters M (2008) Heterologous expression of polycystin-1 inhibits endoplasmic reticulum calcium leak in stably transfected MDCK cells. Am J Physiol Renal Physiol 294(6): F1279-F1286. https://doi.org/10.1152/ajprenal.00348.2007

96. Mekahli D, Parys JB, Bultynck G, Missiaen L, De Smedt H (2013) Polycystins and cellular Ca2+ signaling. Cell Mol Life Sci 70(15):2697-2712. https://doi.org/10.1007/s00018-012$1188-\mathrm{x}$
97. Yamaguchi T, Nagao S, Wallace DP, Belibi FA, Cowley BD, Pelling JC, Grantham JJ (2003) Cyclic AMP activates B-Raf and ERK in cyst epithelial cells from autosomal-dominant polycystic kidneys. Kidney Int 63(6):1983-1994. https://doi.org/10. 1046/j.1523-1755.2003.00023.x

98. Belibi FA, Reif G, Wallace DP, Yamaguchi T, Olsen L, Li H, Helmkamp GM Jr, Grantham JJ (2004) Cyclic AMP promotes growth and secretion in human polycystic kidney epithelial cells. Kidney Int 66(3):964-973. https://doi.org/10.1111/j.1523-1755. 2004.00843.x

99. Yamaguchi T, Pelling JC, Ramaswamy NT, Eppler JW, Wallace DP, Nagao S, Rome LA, Sullivan LP, Grantham JJ (2000) cAMP stimulates the in vitro proliferation of renal cyst epithelial cells by activating the extracellular signal-regulated kinase pathway. Kidney Int 57(4):1460-1471. https://doi.org/10.1046/j.15231755.2000.00991.x

100. Neufeld TK, Douglass D, Grant M, Ye M, Silva F, Nadasdy T, Grantham JJ (1992) In vitro formation and expansion of cysts derived from human renal cortex epithelial cells. Kidney Int 41(5):1222-1236

101. Yamaguchi T, Nagao S, Kasahara M, Takahashi H, Grantham JJ (1997) Renal accumulation and excretion of cyclic adenosine monophosphate in a murine model of slowly progressive polycystic kidney disease. Am J Kidney Dis 30(5):703-709

102. Grantham JJ, Ye M, Davidow C, Holub B, Sharma M (1995) Evidence for a potent lipid secretagogue in the cyst fluids of patients with autosomal dominant polycystic kidney disease. J Am Soc Nephrol 6(4):1242-1249

103. Ye M, Grant M, Sharma M, Elzinga L, Swan S, Torres VE, Grantham JJ (1992) Cyst fluid from human autosomal dominant polycystic kidneys promotes cyst formation and expansion by renal epithelial cells in vitro. J Am Soc Nephrol 3(4):984-994

104. Putnam WC, Swenson SM, Reif GA, Wallace DP, Helmkamp GM Jr, Grantham JJ (2007) Identification of a forskolin-like molecule in human renal cysts. J Am Soc Nephrol 18(3):934-943. https:/ doi.org/10.1681/ASN.2006111218

105. Nagao S, Nishii K, Yoshihara D, Kurahashi H, Nagaoka K, Yamashita T, Takahashi H, Yamaguchi T, Calvet JP, Wallace DP (2008) Calcium channel inhibition accelerates polycystic kidney disease progression in the Cy/+ rat. Kidney Int 73(3):269-277. https://doi.org/10.1038/sj.ki.5002629

106. Chen NX, Moe SM, Eggleston-Gulyas T, Chen X, Hoffmeyer WD, Bacallao RL, Herbert BS, Gattone VH 2nd (2011) Calcimimetics inhibit renal pathology in rodent nephronophthisis. Kidney Int 80(6):612-619. https://doi.org/10.1038/ki.2011.139

107. Janssens P, Weydert C, De Rechter S, Wissing KM, Liebau MC, Mekahli D (2018) Expanding the role of vasopressin antagonism in polycystic kidney diseases: from adults to children? Pediatr Nephrol 33(3):395-408. https://doi.org/10.1007/s00467-0173672-x

108. Pinto CS, Reif GA, Nivens E, White C, Wallace DP (2012) Calmodulin-sensitive adenylyl cyclases mediate AVP-dependent cAMP production and $\mathrm{Cl}-$ secretion by human autosomal dominant polycystic kidney cells. Am J Physiol Renal Physiol 303(10): F1412-F1424. https://doi.org/10.1152/ajprenal.00692.2011

109. Tao Y, Kim J, Schrier RW, Edelstein CL (2005) Rapamycin markedly slows disease progression in a rat model of polycystic kidney disease. J Am Soc Nephrol 16(1):46-51. https://doi.org/10.1681/ ASN.2004080660

110. Shillingford JM, Piontek KB, Germino GG, Weimbs T (2010) Rapamycin ameliorates $\mathrm{PKD}$ resulting from conditional inactivation of Pkd1. J Am Soc Nephrol 21(3):489-497. https://doi.org/ 10.1681/ASN.2009040421

111. Shillingford JM, Murcia NS, Larson CH, Low SH, Hedgepeth R, Brown N, Flask CA, Novick AC, Goldfarb DA, Kramer-Zucker A, Walz G, Piontek KB, Germino GG, Weimbs T (2006) The 
mTOR pathway is regulated by polycystin-1, and its inhibition reverses renal cystogenesis in polycystic kidney disease. Proc Natl Acad Sci U S A 103(14):5466-5471. https://doi.org/10. 1073/pnas.0509694103

112. de Stephanis L, Bonon A, Varani K, Lanza G, Gafa R, Pinton P, Pema M, Somlo S, Boletta A, Aguiari G (2017) Double inhibition of cAMP and mTOR signalling may potentiate the reduction of cell growth in ADPKD cells. Clin Exp Nephrol 21(2):203-211. https://doi.org/10.1007/s10157-016-1289-1

113. Bonon A, Mangolini A, Pinton P, Del Senno L, Aguiari G (2013) Berberine slows cell growth in autosomal dominant polycystic kidney disease cells. Biochem Biophys Res Commun 441(3): 668-674. https://doi.org/10.1016/j.bbrc.2013.10.076
114. Forbes TA, Howden SE, Lawlor K, Phipson B, Maksimovic J, Hale L, Wilson S, Quinlan C, Ho G, Holman K, Bennetts B, Crawford J, Trnka P, Oshlack A, Patel C, Mallett A, Simons C, Little MH (2018) Patient-iPSC-derived kidney organoids show functional validation of a ciliopathic renal phenotype and reveal underlying pathogenetic mechanisms. Am J Hum Genet 102(5): 816-831. https://doi.org/10.1016/j.ajhg.2018.03.014

\section{Answers}

1. d; 2. b: 3. e; 4. c; 5. a 